\title{
Claiming Authority: How Women Explain their Ascent to Top Business Leadership Positions
}

\section{Citation}

Bowles, Hannah Riley. 2012. Claiming Authority: How Women Explain their Ascent to Top Business Leadership Positions. HKS Faculty Research Working Paper Series RWP12-047, John F. Kennedy School of Government, Harvard University.

\section{Published Version}

http://web.hks.harvard.edu/publications/workingpapers/citation.aspx?Publd=8639

\section{Permanent link}

http://nrs.harvard.edu/urn-3:HUL.InstRepos:9830355

\section{Terms of Use}

This article was downloaded from Harvard University's DASH repository, and is made available under the terms and conditions applicable to Other Posted Material, as set forth at http:// nrs.harvard.edu/urn-3:HUL.InstRepos:dash.current.terms-of-use\#LAA

\section{Share Your Story}

The Harvard community has made this article openly available.

Please share how this access benefits you. Submit a story.

Accessibility 


\section{Claiming Authority: How Women Explain their Ascent to Top Business Leadership Positions Faculty Research Working Paper Series}

\section{Hannah Riley Bowles}

Harvard Kennedy School

\section{October 2012} RWP12-047

\footnotetext{
Visit the HKS Faculty Research Working Paper series at: http://web.hks.harvard.edu/publications

The views expressed in the HKS Faculty Research Working Paper Series are those of the author(s) and do not necessarily reflect those of the John F. Kennedy School of Government or of Harvard University. Faculty Research Working Papers have not undergone formal review and approval. Such papers are included in this series to elicit feedback and to encourage debate on important public policy challenges. Copyright belongs to the author(s). Papers may be downloaded for personal use only.
} 
Forthcoming chapter in Research in Organizational Behavior.

\title{
Claiming Authority:
}

\section{How Women Explain their Ascent to Top Business Leadership Positions}

\author{
Hannah Riley Bowles \\ Harvard Kennedy School, 79 JFK St., Cambridge, MA 02138 \\ Tel: (617) 496-4717 \\ Email: hannah_bowles@harvard.edu
}

Author Note

This research was supported by the Center for Public Leadership and the Women and Public Policy Program at the Harvard Kennedy School and by Harvard Business School. The data analyzed in this research were collected in collaboration with Kathleen McGinn and Dina Pradel as part of a larger research project on women and leadership. For thoughtful feedback on evolving drafts of this research, I am grateful to participants in Harvard Business School's Gender \& Race in Organizations Study Group and Organizational Behavior Seminar and to Diane Burton, Robin Ely, Jenny Mansbridge, Kathleen McGinn, Joseph Nye, Maureen Scully, David Thomas, and Andy Zelleke. I also owe thanks to Linda Adamson, Noa Gimelli, Emily Nelson, and Amanda Lee Willis for their excellent research assistance. 


\begin{abstract}
Career stories of 50 female executives from major corporations and high-growth entrepreneurial ventures suggest two alternative accounts of how women legitimize their claims to top leadership positions: navigating and pioneering. In navigating accounts, the women legitimized their claims to top authority positions by following well institutionalized paths of career advancement (e.g., high performance in line jobs) and self-advocating with the gatekeepers of the social hierarchy (e.g., bosses, investors). In pioneering accounts, the women articulated a strategic vision and cultivated a community of support and followership around their strategic ideas and leadership. The career stories suggested that, when the women's authority claims were not validated, they engaged in narrative identity work to revise their aspirations and legitimization strategies. Sometimes narrative identity work motivated women to shift from one type of account to another, particularly from navigating to pioneering. Based on inductive analyses of these 50 career stories, I propose a process model of how women legitimize their claims to top leadership positions by recursively resetting career accounts as authority claims succeed or fail.
\end{abstract}




\section{Contents}

1. Women and the attainment of leadership positions

1.1. An abbreviation of the standard plot of gendered career scripts

1.2. Exploring the counter-narrative

2. Method

2.1. Corporate and entrepreneurial career contexts

2.2. Data collection

\subsubsection{Participants}

\subsection{Data analysis}

3. Navigating

3.1. Aspired authority claims

3.2. Strategies for legitimizing authority claims

3.2.1. Following the rules

3.2.2. Self-advocating with gatekeepers

3.3. Outcomes of authority claims

3.4. Narrative identity work: Navigating beyond a failed claim

3.4.1. Identity work revising navigating accounts

4. Pioneering

4.1. Aspired authority claims

4.2. Strategies for legitimizing authority claims

4.2.1. Building a community of support and followership

4.2.2. Identifying oneself as the natural leader

4.3. Outcomes of authority claims 
4.4. Narrative identity work: Pioneering beyond a failed claim

4.4.1. Identity work revising pioneering accounts

4.4.2. Identity work transforming navigating accounts into pioneering accounts

5. Toward a theory of how women legitimize claims to leadership positions

6. Limitations and implications

6.1. Potential generalization to other career domains

7. Conclusion 


\section{Claiming Authority:}

How Women Explain their Ascent to Top Business Leadership Positions

The widening ascent of women into top leadership positions in major corporations and entrepreneurial enterprises creates an important theoretical opportunity for the study of gender in leadership (Gutek, 2001). Scholars of gender and leadership have a strong theoretical grasp on why women typically do not attain top leadership positions but only a weak command of why some women $d o$. Women in top business leadership positions defy the gendered patterns of career advancement that are so well documented in the literature. Moreover, in doing so, they may actually be rewriting the deeply institutionalized career scripts that have historically cued men and women to follow diverging work trajectories (Barley, 1989).

"I never dreamed that one day I would become Secretary of State," Madeleine Albright, the first female U.S. Secretary of State, once said. "It's not that I was modest; it's just that I had never seen a Secretary of State in a skirt” (Albright, 2000). Albright then famously blazed the trail for Condoleezza Rice in the Bush Administration and Hillary Clinton in the Obama Administration. Albright's example is illustrative of the sex segregation of promotion ladders (Baron, Davis-Blake, \& Bielby, 1986; Cohen, Broschak, \& Haveman, 1998) and the social construction of gender and work (Eagly \& Karau, 2002; Eagly \& Steffen, 2000; Heilman, 1983). Through the power of their own precedent-setting examples, women who ascend to senior leadership positions traditionally held by men have the potential to alter gendered career aspirations and to break open career paths for other women.

If scholars of gender and leadership fail to give adequate voice to the stories of women who have overcome gendered barriers to career advancement, then they risk reifying the 
phenomenon they purport to study. The contemporary literature on gender and leadership is deep and expansive in its explanation of why women fail to "claim authority” (i.e., successfully assert their appropriateness for formal leadership positions, Bowles \& McGinn, 2005; see also DeRue \& Ashford, 2010 and Ely, Ibarra, \& Kolb, 2011 on claiming leadership). Evidence from economics, psychology, sociology, and organizational studies reveals an interlocking pattern of structural and psychological barriers to women’s advancement to top leadership positions (e.g., Eagly \& Karau, 2002; Goldin \& Rouse, 2000; Kanter, 1977; Lyness \& Heilman, 2006; Ridgeway, 2001).

The evocative images of the classic “glass ceiling” (Frenkiel, 1984; Hymowitz \& Schellhardt, 1986) and more contemporary “labyrinth” (Eagly \& Carli, 2007) have come to dominate the narrative about gender and leadership. Even those studies that take as their subject the objective career paths of female executives tend to highlight the barriers to women's advancement, such as need for women to outperform male peers for the same career rewards (Lyness \& Heilman, 2006; Lyness \& Thompson, 2000) and the differential implications of family life for men’s and women’s career advancement (Hewlett, 2002; Tharenou, Latimer, \& Conroy, 1994). They illuminate how even senior women feel pressed against the glass of “a second higher ceiling” after surmounting the first (Lyness \& Thompson, 1997).

The aim of this chapter is to generate new theory from the stories that women tell about their successful claims to top leadership positions. My aspiration is not to challenge the literature on barriers to women's attainment of leadership positions, but rather to broaden the theoretical conversation about women and leadership. I start with a brief overview of the literature on the barriers to women’s attainment of top leadership positions. I follow by proposing what this theoretically mature and well-developed literature could gain from an inductive inquiry into the 
career narratives of women who deviate from its predictions. I present the study methods and findings of two contrasting narratives for how women may establish the legitimacy of their claims to top leadership positions. I close with a discussion of limitations and potential implications of these findings for research on gender and leadership and the study of leadership attainment more broadly.

\section{Women and the attainment of leadership positions}

\subsection{An abbreviation of the standard plot of gendered career scripts}

In a chapter on careers, identities, and institutions, Barley (1989) described how the institutional context of work creates role-defining career scripts (e.g., patterns of symbolic or developmental behaviors that identify individuals with particular jobs or professions). As career scripts are repeated over time, a "standard plot" emerges in which the enactment of nowtraditional career scripts comes to define the social order of the organization, industry, or profession. Although Barley (1989) had little to say about gender specifically, gender is arguably the most deeply institutionalized social cue in human society (Ridgeway, 2011) and has had profound implications for the organization of work (Berger, Fisek, Norman, \& Zelditch, 1977; Bielby \& Baron, 1984; Eagly \& Steffen, 2000; Goldin, 1990).

In this section, I present an abbreviated version of the standard plot of gendered career scripts that lead women away from top leadership positions. Extensive reviews and compilations of the literature on barriers to women's attainment of leadership positions are readily available (see, for instance, Bowles \& McGinn, 2005; Brush, Carter, Gatewood, Greene, \& Hart, 2006; Eagly \& Carli, 2007; Eagly \& Karau, 2002; Ely, Foldy, \& Scully, 2003; Padavic \& Reskin, 2002; Ragins \& Sundstrom, 1989; Ridgeway, 2011; Rudman \& Glick, 2008; Valian, 1999). With 
limited space, I do not do full justice to the depth and complexity of this literature. Instead I outline specifically how gendered career scripts undermine women’s claims to authority.

Top leadership positions are positions of authority (Heifetz, 1994; Selznick, 1957), and the essence of authority is that others recognize one's exercise of power as legitimate (Blau \& Scott, 1962; Katz \& Kahn, 1966; Lukes, 1974; Pfeffer, 1981; Weber, 1947). For this brief review, I borrow as an organizing framework French and Raven’s (1959) three bases of authority: (1) "social structures” that legitimize the distribution of power through systems of hierarchical relations among groups and individuals, (2) “legitimizing agents” who inhabit privileged places within the social hierarchy and have the power to anoint others to positions of authority, and (3) "values” that buttress beliefs in the appropriateness of the social structure and guide the judgments of legitimizing agents (p. 160). The literature on gender and leadership explains well how women are systematically disadvantaged relative to men in terms of their potential to draw on these three bases of authority.

The social structure of the business world reflects a sex segregation of occupations in which women congregate in the lower levels of the hierarchy and in the "velvet ghettos" of staff functions (e.g., human relations) (Gutek \& Larwood, 1987; Reskin \& Ross, 1992). These stereotypically female-dominated career paths lead their travelers away from the core functions (e.g., line jobs) that are the developmental way stations to corporate leadership positions (Catalyst, 1992; Wirth, 2001; Wolf \& Fligstein, 1979). In the entrepreneurial sector, women-run enterprises predominate among small businesses and in low-growth, niche markets, whereas the high-growth, entrepreneurial and venture markets are dominated by men (Brush, 1992; Loscocco, Robinson, Hall, \& Allen, 1991). Women who follow the stereotypical career paths for their gender do not accumulate the requisite skills and experience to succeed in corporate 
leadership or to build high-growth enterprises (Brush, 1992; Doeringer \& Piore, 1985; Loscocco, et al., 1991; Thurow, 1975).

This asymmetric distribution of men and women within the business hierarchy also reinforces perceptions of men’s and women’s appropriate place (Acker \& Van Houten, 1974; Bielby \& Baron, 1986; Cejka \& Eagly, 1999). As a result, conceptions of business leadership and high-growth enterprise have become fused with stereotypically masculine competencies (Bird \& Brush, 2002; Bruni \& Gherardi, 2004; Eagly \& Steffen, 1984; Rudman \& Kilianski, 2000; V. E. Schein, Mueller, Lituchy, \& Liu, 1996). The few women who climb, against expectations, to the highest rungs of the business hierarchy commonly experience social resistance from others and social identity conflict within themselves (Eagly \& Karau, 2002; Ely, 1994, 1995; Goffee \& Scase, 1985; Heilman, 1983; Kanter, 1977) and may need to outperform male peers to demonstrate their fit and worth (Lyness \& Heilman, 2006).

When breaking out of the stereotypical mold, it is even more important for women than men to obtain the support of legitimizing agents who can lend social capital and credibility to their ascent (Burt, 1998). However, in male-dominated work contexts, women tend to have fewer and weaker connections than men to the dominant coalitions (Brass, 1984) that provide the critical resources and opportunities for elevation to top leadership positions (Aldrich, 1989; Brass, 1985; Ibarra, 1992). Efforts to connect women with mentors have not translated into the types of sponsorship that open doors for career advancement (Higgins \& Kram, 2001; Ibarra, Carter, \& Silva, 2010).

Cultural values, which both stem from and reinforce the social structure, further undermine women's potential for top leadership positions by shaping expectations that men will and should be in charge and that women will and should behave in a subordinate (e.g., 
deferential, relational) manner (Acker, 1990; Carli, 1999; Eagly \& Karau, 2002; Eagly \& Steffen, 1984; Ridgeway, 2001; Valian, 1999). Women's claims to status-linked resources are resisted (Bowles, Babcock, \& Lai, 2007), and their dominance displays are rejected (Brescoll \& Ulhmann, 2008; Rudman, 1998; cf., Livingston, Rosette, \& Washington, 2012). Finally, social values and norms regarding women's family responsibilities place women in "time binds" (Hochschild, 1997) that pit work and family against one another in physically and psychologically draining ways (Biernat \& Wortman, 1991; Hochschild, 1990; Mainiero \& Sullivan, 2005) that undermine women's work commitment, aspirations, and capacity to attain top leadership positions.

In sum, the literature on gender and leadership illuminates how women are systematically underprivileged when it comes to establishing the legitimacy of their claims to top leadership positions. They tend to congregate in and be associated with rungs of the social structures that lead, like the lower branches of a tree, outward and away from the top. They are less well connected to the legitimizing agents who could secure their climb, and cultural norms reinforce the structurally embedded gender status hierarchy.

\subsection{Exploring the counter-narrative}

The purpose of the current research is to explore women's career stories that run contrary to the dominant narrative and illustrate how women may establish the legitimacy to claim authority in the highest reaches of the business hierarchy. Career stories provide insight into how institutionalized career scripts shape individuals' aspirations, actions, and interactions (e.g., “I never dreamed that one day I would become Secretary of State...”), but they also provide a window into how individuals reinterpret and improvise from the standard plot (e.g., how the woman who never dreamed of it became the first female Secretary of State) (Arthur, Inkson, \& 
Pringle, 1999; Barley, 1989).

Career stories are also insightful because they are inherently social, constructed in anticipation of an audience and through direct conversation (Ibarra \& Barbulescu, 2010; Strauss, 1959). As such, career stories have the potential to shape collective interpretations of the available career scripts. Stories of disloyalty to the standard plot (e.g., women attaining top leadership positions) carry the spores of institutional reproduction, because they germinate through their telling and retelling in the collective conception of the social order (Arthur, et al., 1999; Barley, 1989; Giddens, 1979; E. H. Schein, 1984; Strauss, 1959; Weick, 2001).

While they are just stories—inevitably biased by retrospection and self-presentation— they provide a valuable empirical lens into how exceptionally high-achieving women in business make sense of their career passages to others as well as to themselves. Their stories reflect a lived experience constructed in interaction with their social environments, including both individual interlocutors who shaped, accepted, and rejected their claims to legitimacy and the organizations they climbed and co-created to become top leaders (Arthur, et al., 1999; Barley, 1989; Ibarra \& Barbulescu, 2010; Weick, 2001). By studying women who have already achieved top leadership positions, we can infer that their stories are ones that have successfully sold others on the legitimacy of their authority claims (Lounsbury \& Glynn, 2001; Martens, Jennings, \& Jennings, 2007). I worked inductively from the career stories of women who had achieved top executive positions in major corporations and high-growth entrepreneurial ventures to generate a preliminary process model of how women legitimize their claims to top leadership positions.

\section{Method}

Consistent with the goal of breaking new theoretical ground in an underdeveloped area of the literature, I used inductive, qualitative research methods (Edmondson \& McManus, 2007). I 
started with an open-ended research question: How do women who have achieved senior positions of leadership in business explain their ascent? My data came from interviews with 50 women who had attained senior leadership positions in major corporations or entrepreneurial enterprises. As described in more detail below, my analyses were exploratory and guided by emergent themes and patterns in the women’s career stories (Glaser \& Strauss, 1967; Miles \& Huberman, 1994; Strauss \& Corbin, 1997).

\subsection{Corporate and entrepreneurial career contexts}

The sample purposefully included a balanced set of women who attained their most senior leadership positions in major corporations and in entrepreneurial enterprises founded by themselves or others (25 corporate, 25 entrepreneurial). Hearing the stories of women who had attained senior leadership positions in corporate as well as entrepreneurial enterprises seemed theoretically important for two reasons. First, corporations represent a more institutionalized context for career enactment than high-growth entrepreneurial ventures, which could have meaningful implications for career improvisation (Strauss, 1978; Weick, 1979, 2001). Second, while there is a documented narrative about women leaving male-dominated corporations to start their own businesses (Moore \& Buttner, 1997), women have had trouble breaking into the top echelons of entrepreneurial as well as corporate leadership and the explanations for why that is have shared roots (Brush, Carter, Gatewood, Greene, \& Hart, 2004; Eagly \& Carli, 2007). The potential to contribute theoretically to the existing literature therefore seemed greater if learning from women’s stories were derived from both sectors than from one sector alone.

As elaborated in the findings, the women's career stories did not cleave evenly along sectoral divides. One might envision the corporate sector as having relatively calcified career paths and cultural norms that would be resistant to adaptation by individual actors, and the 
entrepreneurial sector as having relatively fluid career opportunities and emergent norms that individual actors could more easily mold and negotiate. There was some evidence of this, but no strict dichotomy in the career stories from the two sectors.

The classic images of the corporation in which vertical and horizontal "channels” of movement ensure that “competent men get into the right places at the right time” (Martin \& Strauss, 1956: 101) have less relevance today. As corporate forms have loosened, so that have their bonds on individual careers (Handy, 1998), and the "boundaryless career” (Arthur \& Rousseau, 2001) is replacing traditional models of career advancement in organizations (Hall, 1976; E. H. Schein, 1978; Van Maanen, 1976). Conversely, careers in entrepreneurial organizations are not created in a vacuum (Weick, 2001). The criteria for entrepreneurial success call for rates of growth and expansion patterned on a masculine-stereotyped model (Bird \& Brush, 2002; Cliff, 1998; Goffee \& Scase, 1985; Greene, Brush, Hart, \& Saparito, 2001; Mirchandani, 1999). The feminist proposition that women can escape patriarchal domination through self-employment has received limited empirical support (Goffee \& Scase, 1983; Greer \& Greene, 2003; Winn, 2004). Self-employed women are more likely than wage- or salary-workers to report being married and having children, which suggests that starting new ventures allows them more flexibility to balance work-family conflicts than in traditional organizations (Greene \& Johnson, 1995; Greer \& Greene, 2003). However, the demands of the marketplace for highgrowth enterprises can be as consuming of work-life balance as the most competitive corporate environments (Winn, 2004).

In sum, there are meaningful theoretical reasons to explore women’s career stories from both the corporate and entrepreneurial sectors. Corporate career paths are more institutionalized in many respects than those in the entrepreneurial sector, which should influence the variation in 
career stories. However, in spite of their differences, the two work contexts share many of the same constraints on women's career advancement. In the findings, I attempt to present how the patterns I observed manifested in both sectors, and I highlight dynamics that predominated in one sector as compared to the other. However, in the development of my theoretical story, sectoral variation functioned more to broaden my investigative lens than to divide my sample for comparative analysis (cf., E. H. Schein, 1978 on career anchors).

\subsection{Data collection}

The 50 interviews analyzed for this research were extracted from a larger exploratory study of women's career stories conducted with two collaborators. I excluded from my analysis a small subset of interviews in which women told stories of careers in government service or of nepotistic advancement within established family-run enterprises. These cases differed in important respects from the currently analyzed cases and were too few in number to analyze as distinct career contexts.

Recruitment of the interviewees started with a convenience sample of executives and entrepreneurs who served on two advisory boards of the same university (17/50). Consistent with the principles of theoretical sampling (Glaser \& Strauss, 1967; Miles \& Huberman, 1994), these initial interviews informed the subsequent recruitment strategy. The early interviews reinforced the importance of recruiting equal samples of leaders from corporate and entrepreneurial enterprises and of varying and balancing the industry backgrounds of the corporate and entrepreneurial leaders.

The objective of the research was to study women’s attainment of counter-stereotypical leadership positions. To find women recognized as leaders within the broader business community, we identified additional potential interviewees from published lists or profiles of 
corporate and entrepreneurial leaders. We avoided lists of female leaders because recruitment from such lists could bias the sample toward women recognized as leaders on behalf of women's causes or toward women who might not generally be recognized as business leaders. We made extra effort to identify and recruit minority women. With the exception of one woman of color, we did not recruit women in senior positions in human resource management or government/public affairs because those are more gender-stereotypical positions for female executives.

We formulated a semi-structured interview protocol to elicit information about factors that had enhanced or detracted from a woman's authority as a leader, pivotal events in her career trajectory, how she had gained resources and opportunities for leadership, and barriers to her career advancement. The protocol concluded with some general questions about success factors in attaining leadership positions and advice for aspiring leaders. (See Appendix A for a copy of the interview questions.) I participated in 44 of the 50 interviews analyzed for this research. The 50 interviews analyzed ranged from 45 to 150 minutes. All of the interviews were audiorecorded and transcribed (759 single-spaced pages).

\subsubsection{Participants}

The interviewees in this study were 50 women who had attained senior leadership positions in business. Representative titles at the time of the interview included board chair, chief executive officer, chief financial officer, chief information officer, chief operating officer, director, president, principal, and senior/executive vice president. Table 1 presents descriptive statistics on the interviewees by peak leadership context. As documented in previous research on the career paths of female entrepreneurs (Moore \& Buttner, 1997), most of the women who held peak positions in entrepreneurial ventures recounted pivotal career experiences in corporate 
contexts (18/25). Only two of the 25 corporate executives reported pivotal work experiences in entrepreneurial contexts. The statistics reflect backgrounds at the time of the interview.

The median age of the interviewees was 50 years $(\operatorname{Min}=35$, Max $=68)$. They were 82 percent White/non-Hispanic, eight percent Black, six percent Asian, and four percent Hispanic. Most of the interviewees were married or in long-term partnerships (90 percent) and the majority had children (76 percent), but the women with peak positions in corporate (versus entrepreneurial) contexts were less likely to have partners or children. Ninety-four percent of the women had college degrees and 60 percent had graduate degrees. Of those with graduate degrees, 80 percent had an MBA, 13 percent had a JD, and seven percent reported another type of master's or doctoral degree. Women with peak positions in corporate (versus entrepreneurial) contexts were more likely to have a higher educational degree, particularly an MBA.

Forty-seven of the 50 women were based in the United States, mostly in the Northeast (43 percent) and West (34 percent). Two women were based in Asia, and one was based in Latin America. The three most common industries were financial services, other services, and technology. Sales information was available if the woman was in a full-time leadership position at the time of the interview and the company's financial performance was public information. Based on the information available, the women with corporate careers held leadership positions in businesses with median sales of $\$ 16$ billion $\left(n=21,5^{\text {th }}\right.$ percentile $=\$ 8$ billion, $95^{\text {th }}$ percentile = \$39 billion), and the women with entrepreneurial careers held leadership positions in organizations with median sales of $\$ 16$ million $\left(n=14,5^{\text {th }}\right.$ percentile $=\$ 7$ million, $95^{\text {th }}$ percentile $=\$ 217$ million $)$.

\subsection{Data analysis}

I analyzed the career stories following principles for grounded theory development and 
qualitative data analysis (Glaser \& Strauss, 1967; Miles \& Huberman, 1994; Strauss \& Corbin, 1997). During and following each interview, I made personal notes on how the women described their careers paths and how they explained why they had attained top leadership positions. As I listened to the interviewees and read and reread my notes and their transcripts, I searched for themes and patterns in their stories. I was especially interested in understanding how they established the legitimacy of their claims to top leadership positions. Although this was a question asked directly, the women answered it more implicitly than explicitly in terms of how they told their career stories.

Human agency, in the sense of intentional, future-oriented, self-directed, and selfreflective action (Bandura, 2001), was a dominant theme in most of the women's career stories. For instance, one interviewee explained, "I have a philosophy which is 'You get as much authority as you take.” Another advised: “You have a book to write of your life... Don’t ever let [the company] or anyone else write your chapters. It needs to be your script. Take control.” These types of comments motivated me to ask more probing questions about what the women did to steer themselves through pivotal career transitions (e.g., "Had you asked for this opportunity?”).

Once I began to perceive contrasting accounts (i.e., socially approved explanations, Scott \& Lyman, 1968) of how the women made claim to authority positions, I began iterating between the data and extant literature to develop metaphors for the patterns I was observing (Miles \& Huberman, 1994). To test the subjectivity of my coding, I asked two research assistants to sort a selection of 55 quotes from the 50 career stories into my coding categories. Reassured by high reliability in this test coding $(\kappa=.81, Z=14.31, p<.0001)$, I shifted from interpreting specific career passages to coding patterns in the women’s overall career narratives. I was particularly 
interested in whether the women consistently used the same type of account for their career advancement or if their explanations changed over time and why.

As I gained a deeper grasp of the women’s overall career stories, my analyses centered on two contrasting types of account that the women used to explain their ascent to top leadership positions. As indicated in Figure 1, I have labeled these two accounts “navigating” and “pioneering.” Navigating is a metaphor for accounts in which women explained their ascent to top leadership as a journey from position to position, following institutionalized career paths. Pioneering is a metaphor for accounts in which women explain their ascent in terms of a novel strategic vision around which they developed collective support (e.g., resources, enthusiasm) and followers.

Figure 1 illustrates how I sorted first-order codes of characteristic statements to generate second-order conceptual categories and theoretical sub-categories. For instance, sorting statements about the women's stated objectives helped me to differentiate the aspired authority claims in the two accounts. Navigating accounts consistently started with a desired position or job description, whereas pioneering accounts stemmed from a strategic direction the woman was trying to persuade others to pursue. I further developed my theoretical sub-categories, drawing inspiration from literature on the bases of authority (e.g., Barnard, 1938; Blau \& Scott, 1962; Follett, 1995; French \& Raven, 1959; Katz \& Kahn, 1966; Pfeffer, 1981; Simon, 1976; Stinchcombe, 1986; Stogdill, 1953; Weber, 1947) and on the development of subjective careers (e.g., Arthur, et al., 1999; Barley, 1986; E. H. Schein, 1984; Van Maanen \& Schein, 1977; Weick, 2001) and career-related self-narratives (Ibarra, 2003; Ibarra \& Barbulescu, 2010; Strauss, 1959).

As indicated at the top of the navigating and pioneering columns in Figure 1, I took 
particular inspiration from two contrasting visions of authority in the writings of Max Weber (1947) and Mary Parker Follett (1949). The logic of navigating accounts corresponds with Weber's concept of "legal authority" established on the basis of institutionalized rules of career advancement and organizational promotion. Navigating accounts were about following recognized paths of career advancement. In contrast, pioneering accounts pointed away from well-worn paths toward new directions for others to follow.

In pioneering accounts, the legitimacy of the authority claim depended on the woman's ability to develop a community of followers who saw the collective value in her strategic direction and her leadership role. The logic of pioneering accounts fit Follett’s (1949) fluid (rather than structural) conception of authority as being based on deference to task- and contextspecific knowledge and experience. Follett challenged hierarchical conceptions of authority, arguing that "there is authority all down the line" as superiors and subordinates yield to and rely upon one another's expertise (Follett, 1949; as quoted in Graham, 1995, p. 148). She argued that authority was a "self-generating" process as workers engage collaboratively in complementary roles to achieve collective objectives—derived not from formal organization but "from the intermingling of all, of my work fitting in yours and yours into mine” (Follett, 1949; as quoted in Graham, 1995, p. 154). Successful pioneering required a community of support as opposed to gatekeeper accession.

The majority of interviewees who had attained their peak positions in entrepreneurial ventures described pioneering to new leadership roles (15/25 interviewees). A significant minority of the interviewees who had attained peak positions in corporate enterprises also described pioneering to top leadership positions (6/25 interviewees). With the exception of two serial entrepreneurs, all of the interviewees described navigating at some point in their careers, 
especially in early career stages.

As presented in Figure 1, I devised four theoretical sub-categories for contrasting the navigating and pioneering accounts: 1) the aspired authority claim, 2) strategies of legitimization, 3) the outcome of the authority claim, and 4) narrative identity work to cope with failed claims. “Narrative identity work” refers to efforts to revise self-narratives to meet identity needs and regain social validation (Ibarra \& Barbulescu, 2010). In the following sections, I explicate each of the accounts in terms of these four theoretical sub-categories. See Appendix B for additional examples of navigating and pioneering accounts beyond those presented in the text.

\section{Navigating}

As captured by the quote in the upper left-hand corner of Figure 1, navigating accounts rested on a Weberian logic of rational ascension to authority positions via well-institutionalized career paths.

\subsection{Aspired authority claims}

In navigating accounts, the women described their aspirations in terms of desired leadership positions_-for example, “what I really wanted to be was a CIO” (c23) or "I always wanted to run my own company” (e18). Typically, their stated job aspirations evolved as their careers progressed. Here is how one woman described her response to opportunities to pursue alternative career paths:

I always said, "No, I want to be the best private banker in the world.” And then at different points in my career... I said, "I want to be best leader of a team in the private bank in the world.” And then I said, "I want to build the best private bank in the world.” (c19).

In sum, navigating aspirations involved setting one’s sights on a specific leadership position. 


\subsection{Strategies for legitimizing authority claims}

In navigating accounts, there were two main components to the women's strategies for legitimizing their claims to authority positions: 1) following the rules of career advancement within the social structure and 2) self-advocating with the gatekeepers of career advancement.

\subsubsection{Following the rules}

Consistent with the Weberian logic of "legal authority," many of the navigating accounts detailed how the women worked to meet specific criteria and standards for advancement to their aspired positions. One manufacturing executive explained:

At [my company], it’s important to establish a functional track record. So I developed a deep expertise in manufacturing. I've been a plant manager, done everything you can think of in manufacturing... To get to the kind of position that I have, the company also looks for success in staff-type functions, as well as what we call cross-functional stretch assignments... Another thing the company looks for: international success... I went into [foreign region] as the first woman plant manager in [that region] (c6).

Similarly, navigating narratives by women who started their own business contained an explanation of the women's requisite experience and track record. One entrepreneur recounted, “After [working in a bank], I decided that I could run my own business” selling financial services because "I knew how to manage... and invest money" (e14). Another entrepreneur said she was able to grow her business because "I built a really strong reputation for understanding their business challenges and being able to apply technology” (e22).

Even when family commitments steered them away from the most well-recognized and highly valued career paths to top leadership positions, the women explained how they found 
other avenues to demonstrate their leadership potential. A corporate executive said:

Because my husband [had an established professional practice], I couldn’t... just pick up and go to [another city] for two or three years. And so I raised my hand and said, you know what, I'd actually like to run [this local office]... I was probably the only person who ever volunteered to go [to that side of the business], because usually you were put out to pasture in [there]. And there were people who said to me, “...You’re sacrificing your career. You’re going to go into a dead end.” And I never really saw it that way at all. ... [The company] at the time wanted to send the signal that—because [that side] was really growing very fast...- - this was a place where the most talented people, not the least talented, people actually would go. So, I was over there... and did very well... and within a year or two I was made the managing director (c13).

In another representative example, an entrepreneur commented:

[I] was completely reinventing myself and starting from scratch because I had two young children and wanted to work along a different path... The fact that [I] could have worked at one of those places, but chose not to, didn't really help. You still didn't have the cachet of that name. I think that does undermine the authority and the heft that you bring to the table... [But, in my business], it's like a baseball team. If you... put on a great performance and you lose, then you are not a good team... When you win...it sort of feeds on itself. ... What really matters in the end is the scorecard-how your company performs. (e15) 
Even though they acknowledged veering from the dominant career path to top leadership, these women expressed confidence that they knew the system well enough to establish themselves along a less-travelled route.

\subsubsection{Self-advocating with gatekeepers}

Self-advocating with the gatekeepers of career advancement (e.g., bosses, recruiters, etc.) was a recurring theme in navigating narratives, particularly in corporate contexts. One navigator, who built her career in corporations but attained her peak position in an entrepreneurial venture, explained: “I’m a firm believer you never get anything you don’t ask for” (e17). Here she recounts conversations with corporate recruiters:

I’d say, “Well look, I’m really interested in joining [your company]. What do you think my opportunities are for developing into a significant career?”

“Great. You can be vice president of marketing...[or] operations.” I said, "Well, can I be president?”

“No."

"Why not?"

“You're not an engineer... It's not really important in terms of being the president..., but it's very important in terms of credibility within the company.” So,...I said, “Look, ... I'm not going to start where the end point is curtailed...”

[At new company,] I totally asked this question: “Do you see me as potential presidential material? ... Can I restrict my career to [where I am living now] for the next five years without really damaging it?”

So we had all these negotiations upfront... "This is what I want. Do you 
see any reason why I can’t have it, provided I perform against your criteria?”

Numerous quotes from navigating narratives of women in corporate contexts echoed the importance of this type of self-advocacy for career advancement.

Complementing the strategy of asking for desired opportunities was the strategy of refusing undesirable ones that would steer women away from their aspired path, as illustrated in this quote:

I'd been running a business unit and [company management] came to me and offered to make me a VP, basically of the kitchen. (Laughs.) I forget what it was called. And I just looked them in the eye, and I said, “I haven’t invested my education and my career to go run the kitchen.” And they said, "Fine.”...Six months later, I became Vice President of an operating unit... They were looking for ways to accelerate women but...there was absolutely no way I was going to go [run the kitchen] (c20).

In sum, as one navigator explained, "How do you get the job? Bottom line: performance... But the other thing is ask for it” (c6).

\subsection{Outcomes of authority claims}

I refer to a successful authority claim as "validated” in the sense of being rendered legal or corroborated (Oxford English Dictionary). This notion of validation aligns with the idea that authority as a legitimate exercise of power, by definition, requires social acceptance. It also works with either a Weberian or Follettian logic for the recognition of authority.

In navigating accounts, authority claims were validated when the woman achieved her desired position in a corporate or entrepreneurial enterprise (e.g., becoming a C-level executive 
or running her own business). Navigating accounts of failed authority claims typically centered on a lack of support from the gatekeepers of career advancement. For instance, a number of the women cited "politics” or the “old boy’s network."

In the following quote, a finance executive describes a failed authority claim that motivated her to move to a different bank:

Though as a woman I never felt discriminated against, I always felt that I was much more highly valued by my clients than by the people I worked with. There was almost a feeling, "Well, how could she do it. She's not as tough as I am.” One partner once said, “Well, gee, my wife couldn’t do this.” So you've got this feeling that I was viewed through a certain optical vision that was not direct. It was colored by all sorts of other things (c18).

Another executive recounted talking to a former colleague about why she had left his company: We were chatting... for a while, and I just basically said, “Hey, I didn’t really think I'd ever get a shot at a line job at this level in [your company].” And he said, "You're right. There still is no woman with that kind of responsibility [at our company].”... Finding the advocacy that is willing to give you the opportunity to do what you're capable of doing... I think it's the toughest barrier (c6).

Perhaps because all of the women in the sample were so high achieving, none attributed failed authority claims to their own underperformance.

\subsection{Narrative identity work: Navigating beyond a failed claim}

The interviewees' career stories suggested that, when their authority claims were not validated, they engaged in narrative identity work to update how they explained their career aspirations to themselves and others (Ibarra, 2003; Ibarra \& Barbulescu, 2010). They then 
aligned these updated aspirations with a revised set of legitimization strategies. To facilitate comparison of narrative identity across the navigating and pioneering account, all of the examples of narrative identity work that I present in the text follow the experience of being fired. Being fired is a prototypical example of a situation that prompts identity work in achievementoriented professionals (Ibarra, 2003; Ibarra \& Barbulescu, 2010; Newman, 1999). Appendix C displays supplemental examples triggered by other types of experiences.

\subsubsection{Identity work revising navigating accounts}

Narrative identity work following failed navigating accounts sometimes led to a revised navigating account (e.g., new insights into job preferences). One repeat navigator characterized being fired as one of her most pivotal work experiences. Before the acquisition that precipitated her firing, she said she was the "number one-ranked...professional” in her functional area: "Here I am this pretty young person, and I get a half a million dollar bonus... It was unbelievable.” But she said she did not fit the culture, specifically, "I was not part of the old boy network" (c19). She said she was replaced by someone who operated more effectively within the culture, “because the [new] person...could do all of that stuff. And I couldn’t do it” (c19).

While this time was clearly painful, she describes it as a period of personal growth and constructive redefinition of her job preferences:

I look back on that and I am so thankful... I learned so much about myself. I learned that the whole point is making a life decision, not a career decision... And out of that... I had this [new] list of [job] criteria, and the first one was location [for family proximity], the second one was type of company, the third was type of position, and the fourth was compensation... And if I got a job offer-because I had a number fairly quickly — [that didn’t meet] those criteria... I was able to turn 
them down. I had the courage to do that (c19).

She then explained how she pursued a new position through self-advocacy and demonstration of the leadership competences that would be valued in her target corporation. In sum, the invalidating experience of being fired motivated her to rethink how she had been mapping her career and to start navigating anew along a revised route.

\section{Pioneering}

As indicated by the quote in the upper right-hand corner of Figure 1, pioneering accounts reflected a Follettian logic of authority as the integrative product of collective collaboration. In this more fluid than structural conception of authority, deference is paid not to the institutionalized social hierarchy but to leadership that is recognized to serve the collective good.

\subsection{Aspired authority claims}

In contrast to navigating accounts, pioneering accounts started with a strategic direction as opposed to a desired job description. Sample strategic objectives included corporate globalization, improved financial or information processes, and new products or services. In the following quote, a corporate executive described her vision of transforming a package of financial services that she devised into a business line for her company:

I had been back in the sales side for maybe about four years... I had an idea to take what I was doing for [the company] and really make it big and really turn it into a business for [the company]. ... I approached our CFO and... of course his reaction was, “Well, I'd love to see a business plan.”... I did the business plan... [and] part of the plan was that... I would be the person who would run it for the corporation. (c3) 
This quote is characteristic of the aspirations articulated in pioneering narratives. It opens with the woman raising a strategic goal (i.e., create a new business line) that sets the stage for a new leadership opportunity (i.e., a business line that she will run). One serial entrepreneur who shared numerous examples of pioneering new leadership positions summed up her career story by saying, "I think my leadership attributes really spring from my own vision and conceptualization of products and services that are not in the marketplace” (e3).

\subsection{Strategies for legitimizing authority claims}

In pioneering accounts, the two main components to legitimizing authority claims were (1) building a community of support and followership and (2) identifying oneself as the natural leader to guide the community in a new strategic direction.

\subsubsection{Building a community of support and followership}

In navigating accounts, the most prominent “legitimizing agents” (French \& Raven, 1959) were the gatekeepers of career advancement within the social hierarchy. In corporate contexts, these were typically senior executives with the power to hire, promote, and fire. For entrepreneurial navigators, they included major customers and investors essential to business growth. In contrast, in pioneering accounts, the women sought buy-in from a broad community potential supporter and followers. These communities included the gatekeepers highlighted in navigating accounts as well as a base of other stakeholders—ranging from potential customers to colleagues to the media — who validated the importance of the woman's strategic ideas and her rightful leadership of them.

In the following quote, a corporate executive explains how her new leadership role was legitimized by her identification with a strategic idea whose value had finally become widely recognized: 
[Company] came back to me and said ... "We want to globalize... It's the one thing you've said to us for years. We're a federation of companies. We're not a global organization. So could you come and help us do this?” ... It was the opportunity to globalize that really, really got my juices going to go back... This was one of my mantras: We need to globalize... They didn’t come after me because [of my track record as a] CFO. I'm good, but I'm not great... What I had that others didn't is that I understood and knew the cultures and the [systems of the organization]... and [I] had a passion to do this work [of globalizing]. (c1) Some entrepreneurs, such as the following, described a similar awakening within their market segment to the importance of their ideas:

Somewhere along the line, I began to hear it. Somewhere along the line I began to teach [a] class on it ... and that led to my writing a book about it. Then ... the book was published, and...I had kind of a national reputation... I was the only person who had written a book about it, so I suddenly was the person invited into every boardroom to discuss [strategic issue]. So, I had this kind of opportunity to be in institutional settings, up close and personal, trying to convince them to do something (c1).

This conception of authority being granted to serve the good of the collective is reflected in classic writings on authority. For instance, Milgram (1974) and Kelman and Hamilton (1989) argued that compliance to the exercise of authority is more likely when the exercise of power resonates with potential followers’ self-interest and values. 


\subsubsection{Identifying oneself as the natural leader}

In navigating accounts, the women self-advocated with the gatekeepers of career advancement to achieve their aspired positions. In pioneering accounts, the women selfidentified as the natural leaders of their strategic pursuits. For instance, in the following story, a woman explains how she became $\mathrm{COO}$ by identifying herself as the champion for new financial systems in her organization:

When I replaced the senior vice president of finance, I stood up in front of the 1,500 person finance team and said, "I commit to you: we will have new financial systems.” Then I began a campaign to get the financial systems funded... I got the funding approved and selected the software. [The new CEO] came on board...[and ] I said, "We’re putting [software] in.” He looked at me and said, "You are crazy!...” So I said, “OK, I have to build consensus.” ... Other companies who had had successfully implemented [software]...helped me build a business case... I achieved my goal through collaborative work with the team, got it approved, and delivered it... I told [the CEO] in his office...that "in order for me to be effective in what you're asking me to do...” I needed to be his direct report. I could not be effective without that change. And it happened... He responded with an offer...Immediately—same day. (c16)

In pioneering accounts, another way the women described gaining buy-in and selfidentifying as the natural leader was to use personal stories to illuminate their strategic ideas. The following story illustrates this approach:

I developed a profound allergic reaction to a drug... It took me over three years to really heal myself by eating foods that were whole and real and natural, because 
the medical profession...[was] not able to help me... I was so impressed with how I felt... and yet so thwarted and exasperated by trying to find the foods that were real and wholesome-remember there were no major whole food stores at the time - that I decided to open up... a supermarket...that contained nothing but whole, real, natural foods, using a food philosophy and definition that I had defined in regard to the foods that I would carry (e6).

According to this woman's pioneering account, her strategy for growing her company was an education campaign aimed at building a community of believers among her customers, employees, and potential investors.

Customers came in, they duplicated my statements, they understood what I was talking about, and I used my teaching skills to incorporate the entire supermarket, which was the largest of its kind in the entire world, as a laboratory for education and information. ... Being the niched person, and going out and talking to the media, being interviewed by the media... it’s more than saying, “Oh, well, we're a \$90 million a year business.” ...It's more than that... What you're doing is you're writing about the developed romance, the reason why, the story, so that there is buy-in...there’s an emotional tug. There's a feel (e6).

Through storytelling and education, this woman cultivated a following around her strategic issue. By becoming the storyteller of why people need to follow in her strategic direction, she situated herself in a central role in the achievement of that strategic objective. Such storytellers attract customers, media attention, resources, and support, which in turn enhance the legitimacy of their leadership claims.

Another approach the women used in pioneering accounts was to seek out forms of 
public recognition that would publicize their strategic issue and identify themselves with it. In the following corporate example, a woman described using the media to build stakeholder support inside of her company:

So, I thought to myself, “If I can leverage the value of what I'm doing for the company as a whole, in addition to bringing business into the business lines, I think that's going to get me more resources and more acceptance of really leading something serious here.” ... I started doing things that would garner a lot of favorability to the company. So when they would see CNN or Business Week, The Wall Street Journal, [they would see] feature stories on [my issue] with either what [my company] was doing or quotes from [me]. ... things that really were going to get noticed at the top... because it benefited the [company] overall... Of course [other employees] liked it... [They] would come up to me and say, "I really love what you do; it makes me feel good about my job...” Or "I love what you do because it... makes me feel good about the company.” So it was one of those interesting ways of getting recognized” (c4).

Other women described a similar strategy of bootstrapping one form of recognition to gain another, as in this corporate example:

In the last couple of years, [my issue has] brought more press to [the company] than any other part of the organization. We've won awards. We've been in every major form of media. It became a self-fulfilling prophecy... And it was featured actually last year in [the company]'s Annual Report. (c3)

A number of the entrepreneurs wrote books to spread their messages and self-identify as intellectual leaders on their strategic issues. As one woman explained, “I finally decided one way 
of establishing some legitimacy was to actually put down in an indisputable form what I did know about the area. So I wrote a book" (e8). She continued to explain how interacting with people about the book became a “catalyst” for her organization’s growth.

In sum, in pioneering accounts, the women explained the legitimacy of their authority claims in terms of their ability to persuade others of the importance of and collective value in their strategic ideas. They did so by appealing to the interests and values of key stakeholders (e.g., sales pitches, business plans), telling stories that motivated people to connect at a personal level to their strategic issues, and demonstrating growing social consensus through public recognition. Another essential component of establishing the legitimacy of their authority claims was to identify themselves as the presumptive leaders of their strategic issues—as the experts, storytellers, and passionate champions for their cause.

\subsection{Outcomes of authority claims}

Validated authority claims in pioneering accounts typically involved the development of a new organizational form or entity for the women to lead, such as an entrepreneurial venture or a new or reorganized business function within a corporation. When authority claims were not validated in pioneering accounts, it was for a lack of buy-in from critical legitimizing agents (e.g., customers, senior executives, investors, etc.).

\subsection{Narrative identity work: Pioneering beyond a failed claim}

When the women's pioneering accounts were not validated, they described narrative identity work to revise their pioneering accounts with the same or a new strategic objective. In some cases, it was a failed navigating account that motivated the women to shift to a new pioneering account. To facilitate comparison with my example of identity work updating a navigating narrative, I illustrate these dynamics with two contrasting career stories in which the 
women involved were fired.

\subsubsection{Identity work revising pioneering accounts}

In this section, I present an illustration of a shift from a failed pioneering account to a renewed one. The woman recounted being fired after trying to lead a new initiative within her company. She explained, "I ended up in an open dispute with my management and... leaving... under a cloud” (e8). While senior management had failed to validate her strategic idea, she said other employees recognized her leadership, and many followed her out the door: "I left, and something like 70 percent of the entire organization left after me. So, ironically, I was in a position of having been fired from a spot, but having also got [a leadership award]...for that year” (e8). She recounted that the discordant experience of being fired yet partially validated reinforced her belief in the power of her ideas:

I think actually getting the award in combination with seeing that community dynamic at work was real, real powerful. It ... indicated to me that ... I could have a world that agreed with my view of how things worked... That was an epiphany for me (e8).

After departing the organization, she wrote a book about her ideas and, eventually: I set out and found folks who were functioning on the same wavelength as me, and was able to leverage that community of peers and like-minded folks into what became and still is considered one of the most functional...partnerships [of the type she originally proposed] (e8).

In sum, in her initial pioneering narrative, she was not able to gain sufficient buy-in to lead her organization in a new strategic direction — her authority claim was not validated. However, the insights she gained from this experience about her potential to realize her ideas motivated her to 
update her aspirations, enhance her profile and credibility as an expert on her strategic issue, and then build, in an entrepreneurial way, a new community of supporters and followers around her leadership and ideas.

\subsubsection{Identity work transforming navigating accounts into pioneering accounts}

In a number of cases, interviewees described how failed navigating accounts motivated them to focus their attention on their own strategic business ideas, which then shifted them from a navigating to a pioneering logic in their career story. In one representative example, the woman started with a navigating account of how she rose to higher levels of authority within one company: "I got the job as Director... About a year into it... I told [the founder/CEO] I wanted to be...a vice president” (e21). He promoted her and continued to expand her authority based on exceptional sales performance.

With success, her job aspirations rose. She explained, "I was beginning to really sprout my wings, and feel the walls a little bit” (e21). She gave the founder/CEO an outline for a new business venture she wanted to lead. She said this proposal led to her firing:

So he asked me to come to his office... I was thinking, "Wow, I’m going to get everything I ever dreamed about.”... And he handed me a big box and told me my services were no longer needed. ... Shame on me, a little bit... He had given me, I have to admit, great opportunity to grow... I think it might have been a shock to him that I had an original idea... I had no idea that he would take that so personally... He let me go (e21).

This story of being fired sets the scene for the story of how "my life really began as an entrepreneur” (e21), as the experience sharpened her aspirations to pursue her own strategic ideas. She recounts: 
There’s nothing worse than being fired and there’s nothing better than being fired, because it stirred up something I had never imagined was alive and kicking with me, which was... that I wanted to start my own business. I had a great idea. It must have been great if he fired me...it must be fabulous (e21).

From this juncture, her career story shifts to pioneering and she details how she devoted herself to gaining support for her new business ideas—-telling potential advocates, investors, and customers “about my vision” (e21).

\section{Toward a theory of how women legitimize claims to leadership positions}

In Figure 2, I propose a process model of how women legitimize their claims to leadership positions, which is inductively derived from my analyses of womens' career stories. The model flows from setting aspirations to enacting strategies to legitimize the woman's authority claims. Authority claims are then validated or not. If they are validated, I propose that the women revise their aspirations again. If the claims are not validated, I propose that the women engage in narrative identity work to revise their aspirations and devise new strategies for legitimizing their authority claims.

As described in the findings, the navigating and pioneering accounts represent two distinct approaches to articulating leadership aspirations and establishing the legitimacy of one’s authority claims. In navigating accounts, the aspirant articulates a desired position and then attempts to demonstrate her qualifications for that position according to institutionalized rules of career advancement. Another typical strategy in navigating accounts was for the aspirant to selfadvocate with the gatekeepers of career advancement to elevate her into higher levels of authority. In pioneering accounts, the aspirant articulates a novel strategic direction in which she would like to lead her current or a new organization. The legitimization of authority claims 
involves building a community of supporters and followers of her strategic vision and leadership.

As illustrated by the flow of arrows in the right-hand side of Figure 2, I propose that the experience of a failed authority claim triggers identity work to revise or replace unsuccessful accounts. At this point, the women's career story could continue to follow the same logic; failing navigating or pioneering accounts could simply be revised. But I also propose that narrative identity work presents an opportunity for a shift in career logic from navigating to pioneering, and vice versa. In the findings, I illustrate this type of logical shift with one representative example of a woman whose experience of being fired motivated her to shift from seeking a bigger job (following a navigating logic) to pursuing the realization of her strategic vision for a new business (following a pioneering logic).

As crafted, Figure 2 suggests that career stories could also flow from pioneering accounts through identity work into navigating accounts. There were, however, no explicit career stories told in this pattern in the sample. There were pioneering accounts in which interviewees described relocating from one employment situation to another before gaining sufficient backing to pursue a new strategic direction, but none of the women described abandoning a strategic vision because they changed their mind about the type of job they wanted (i.e., exchanging pioneering for navigating aspirations).

When I have presented these data and ideas to female executives, a number of senior women have volunteered stories of moving from pioneering to navigating narratives late in their careers. After engaging for decades in the immersive work of developing communities of followers around their strategic ideas, they described reaching a stage of life in which they sought particular types of positions (e.g., to play the mentor, finding more work-life balance). Perhaps because almost all of the women in this sample of interviewees were at or approaching 
career peaks, this dynamic was not evident. It still seems reasonable to propose that career stories may follow the upward as well as downward flow depicted in Figure 2.

In sum, as illustrated in Figure 2, I propose that the process of claiming authority is a recursive exercise of setting aspirations and accounting for the legitimacy of one's claims to authority positions. The logic of the accounts that one employs is likely to be a product of individual differences and work contexts. Navigating accounts predominated in corporate contexts, although they were also clearly evident among high-achieving entrepreneurs. Pioneer accounts were more prevalent in entrepreneurial than corporate contexts. However, 25 percent of the pioneering accounts were situated in large corporations and led to the creation of new business lines or strategic reorganizations.

\section{Limitations and implications}

A limitation and opportunity in this research is that it suggests a great deal more work to be done to flesh out in more theoretical and empirical detail what actual behaviors and career choices, self-presentational strategies, and mental mindsets might help more women advance to higher levels of authority. While there are distinct advantages of learning from positive deviants (Sternin, Pascale, \& Fisher, 2009), future research is needed to investigate how these accounts might be employed by broader populations of women and men.

Typical of many inductive explorations, certain elements of my findings are not "news." The navigating narratives, in particular, are strongly reflective of the literature on careers in organizations. Careers have long been conceptualized as tournaments in which employees compete according to institutionalized standards for career advancement (e.g., O'Neill \& O'Reilly, 2010; Rosenbaum, 1979; Sheridan et al., 1990; Thomas \& Gabarro, 1999). Selfdirected career advancement is a central characteristic of contemporary career models (e.g., 
Arthur, Inkson, \& Pringle, 1999; Arthur \& Rousseau, 2001; Hall, 2002). The value in sponsorship for career advancement is also well established (Higgins \& Kram, 2001; Ibarra, Carter, \& Silva, 2010; Thomas \& Kram, 1988). However, while familiar in many respects with the careers literature, these navigating accounts highlight thought-provoking tensions with literature on gender and leadership, particularly the research on social backlash against women’s self-promotion for career advancement (e.g., see Rudman \& Phelan, 2008).

Self-advocacy was a dominant theme in the women’s navigating narratives, particularly in corporate contexts. But the idea that women get ahead through self-promotion contradicts the predictions of research on gender-stereotype-based constraints on women's workplace behavior. There is a well-developed literature on how self-promotion violates prescriptions of the feminine stereotype and triggers social backlash against women striving on their own behalf for career rewards (Amanatullah \& Morris, 2010; Bowles, Babcock, \& Lai, 2007; Rudman, 1998; Rudman \& Glick, 2001). Why do these women seem to get away with it? Indeed, many of the interviewees described self-advocacy as essential to their career advancement.

This disconnect—between the women’s organizationally grounded career stories and a social-backlash literature that is primarily laboratory based-suggests new research questions for the study of women's career development. What might these stories suggest about potential moderators of backlash effects? For instance, in most laboratory-based research on social backlash against agentic women, the targets and evaluators are typically previously unknown to one another, and researchers usually control the scripts so that men and women assert themselves in the same verbal and nonverbal manner. Future research could explore how the quality of women's relationships and reputations moderate the evaluation and effectiveness of their selfadvocacy. It is also possible that there are important nuances in the verbal or nonverbal strategies 
that these women used to self-advocate.

Laboratory research suggests that a high propensity for self-monitoring helps women evade the constraints of prescriptive stereotypes (Flynn \& Ames, 2006; Rudman \& Phelan, 2008), but we do not yet fully understand the mechanisms through which self-monitoring is effective. For instance, did the deep knowledge of the institutionalized norms of career advancement evident in the navigating accounts reflect high self-monitoring? Would a high propensity for self-monitoring make it easier for women to craft accounts for their authority claims that would appeal to organizational values and standards of legitimacy? The career stories analyzed for this research do not give us enough data to answer these questions, but they suggest an imperative for expanded inquiry and highlight the potential to learn from women who have evaded traditional barriers to women’s attainment of top leadership positions.

A related question that arises from the pioneering narratives is whether self-presenting as an advocate of strategic business ideas relieves women of the gender binds of self-advocacy by allowing them to claim authority in the name of their cause as opposed to their own career advancement. Psychological research suggests that women are more effective when advocating for others than for themselves because they are less concerned about social backlash (Amanatullah \& Morris, 2010; Bowles, Babcock, \& McGinn, 2005). Self-consciousness about the potential for social backlash is cognitively draining (Moss-Racusin \& Rudman, 2010) and can distort women’s leadership behavior (von Hippel, Wiryakusuma, Bowden, \& Shochet, 2011). Writing on women’s leadership development Ely, Ibarra, and Kolb (2011) argue that women can develop a more resilient leader identity through "an elevated sense of purpose and conveying that sense to others” (p. 476). Pioneering accounts for authority claims fit this advice.

Future research could explore the enactment as well as telling of pioneering accounts. 
From a social-psychological perspective, researchers could explore how evaluators respond to pioneering as compared to navigating accounts of women’s career development and whether women experience more psychological relief from the burdens of self-promotion when accounting for their leadership aspirations in terms of ideas as opposed to personal career advancement. From a careers perspective, richer theory on pioneering could be developed from entrepreneurial research on storytelling (Lounsbury \& Glynn, 2001; Martens, et al., 2007), organizational research on issue selling in corporations (Ashford, Rothbard, Piderit, \& Dutton, 1998; Dutton \& Ashford, 1993), and the study of tempered radicals (Meyerson, 2001) and boundaryless careers (Arthur \& Rousseau, 2001; Weick, 2001).

Another potentially theoretically important connection this work makes between the broader careers literature and the literature on women and leadership is through narrative identity work (Ibarra \& Barbulescu, 2010) as a vehicle for overcoming barriers to women’s career advancement. Many of the women attributed failed authority claims to gender-related barriers (e.g., implicit gender discrimination, exclusion from male-dominated social networks). Deeper investigations of women's narrative identity work could enrich our understanding of how women persevere in spite of gendered barriers to their career advancement.

\subsection{Potential generalizations}

The process theory proposed in this research is based on the career stories of women in business. But there is suggestive evidence from the autobiographies of women in top government positions that women also employ navigating and pioneering accounts to claim authority in the public sector. For instance, in her memoir, Madam Secretary, Madeleine Albright describes navigating from the position of U.S. Ambassador to the United Nations to the position of U.S. Secretary of State: 
My years at the UN had given me much on-the-job experience and a hefty dose of public exposure. ... when White House Chief of Staff Leon Panetta surveyed cabinet members about our future plan, I said..., "I would love to continue serving at the UN, but I would also be interested in becoming Secretary of State...”...Some of the Democratic Party’s most influential “wise men” advised me early on not to "campaign" for the job. I thought $h m m m$... I doubted [the male candidates] were sitting demurely at home waiting for the phone to ring. I was sure they would do everything they could to activate their network of supporters. ...As the non-campaign for secretary began, my own network was small... but it did include some smart and determined people. ... I didn’t want the President to reject me because his advisors couldn't envision a female secretary of state. At the same time, if he did select me, I wanted it to be on the basis of merit, not gender (Albright, 2003, pp. 215-219).

In her description of the process of becoming both the UN Ambassador and the U.S. Secretary of State, Albright uses a navigating logic to account for her ascent. She recounts targeting particular positions and then establishing the legitimacy of the authority claim based on the rules of career advancement within the foreign policy establishment and the Democratic party (e.g., professional credentials and experience, political connections). At critical junctures, she makes direct appeals to the presidential advisers who are the gatekeepers of the top political appointments.

In her memoir on The Path to Power, Margaret Thatcher uses a pioneering account to explain how she became the British Prime Minister. Her story of her ascent starts with strategic concerns about the weak leadership of her Conservative Party and her belief in the need to “provide a backbone for Conservative social policy” (Thatcher, 1995, p. 262). She explains how 
she was committed to challenging the leadership of her party, at first backing a colleague, Keith Joseph, to run for the top position. When Joseph folded under political pressure, she recounts, "I heard myself saying: 'Look, Keith, if you are not going to stand, I will, because someone who represents our view has to stand’” (p. 266). She describes her initial leadership aspirations as selfless, full of dim hopes for success and commitment to the cause:

Though I had few ideas about how to proceed, I was sure my reaction to Keith has been the right one. [The party leader] had to go, and that meant someone had to challenge him. If he won, I was politically finished. That would be sad but bearable... And it seemed to me most unlikely that I would win. But I did think that by entering the race, I would draw in other stronger candidates who, even if they did not think like Keith and me, would still be open to persuasion about changing the disastrous course on which the Party was set (Thatcher, 1995, p. 267).

As Thatcher goes on to describe her now-famous campaign to set a new course for the Conservative Party, it stemmed from the perceived legitimacy of her ideas and her representation of them rather than her professional qualifications.

I am confident that expanded analysis of the career stories of men and women in top leadership positions would also reveal patterns of both navigating and pioneering. While the career stories that motivated this research are in many respects distinctively gendered, the process theory proposed in Figure 2 is not obviously so. Because women hold lower status in society relative to men (Ridgeway, 2011) and because senior leadership remains a masculine stereotyped role in our society (Eagly \& Karau, 2002), women may need to be even more strategic than men about establishing the legitimacy of their authority claims. But, men too need 
to legitimize their claims to leadership positions (DeRue \& Ashford, 2010).

One question of gender difference that would be worth investigating is whether pioneering —a less documented strategy in the careers literature—might be more strongly associated with women's top leadership attainment than men’s. Using a pioneering as opposed to navigating account might help women evade gendered constraints on their self-promotion by depicting the them as advocates of ideas and the collective good (e.g., see Ridgeway, 1982). Pioneering might also help women sideline gender-stereotypic questions about their competence and qualifications for a “man’s job.” Just a few months before winning the leadership of the Conservative party, Margaret Thatcher argued, “'I think it would be extremely difficult for a woman to make it to the top... [because] to get to that very top one has to have experience in one of the three important posts’” (i.e., the traditionally male-occupied roles of Foreign Secretary, Chancellor of the Exchequer, or Home Secretary) (p. 261). Although she could have not have foreseen it then, her pioneering career story would revise this standard plot of leadership attainment.

\section{Conclusion}

Much more theoretical attention has been paid to the barriers to women’s advancement than to how women may overcome them. Investigation of the experiences of women who defy the standard plot of gendered career advancement creates an opportunity for theory development. Drawing on the career stories of high-achieving female executives and entrepreneurs, I propose two accounts that women might use to establish the legitimacy of their claims to top leadership positions. I hope my analysis of these career stories will widen readers' imagination when they think of women and leadership and open new directions for research on how women claim authority in spite of the barriers to their career advancement. 


\section{References}

Acker, J. (1990). Hierarchies, jobs, bodies: A theory of gendered organizations. In J. Lorber \& S. A. Farrell (Eds.), The social construction of gender (pp. 162-179). Newbury Park: Sage Publications.

Acker, J., \& Van Houten, D. R. (1974). Differential recruitment and control: The sex structuring of organizations. Administrative Science Quarterly, 19(2), 152-163.

Albright, M. (2000). Carry your fair share of the burden. Keynote Address at Northeastern University's 98th Morning Commencement. Retrieved May 2012: http://www.northeastern.edu/magazine/0009/albright.html

Albright, M. (2003). Madam Secretary: A memoir. New York: Miramax Books.

Aldrich, H. (1989). Networking among women entrepreneurs. In O. Hagan, C. Rivchun \& D. Sexton (Eds.), Women-owned businesses (pp. 103-132). New York: Praeger.

Amanatullah, E. T., \& Morris, M. W. (2010). Negotiating gender roles: Gender differences in assertive negotiating are mediated by women's fear of backlash and attenuated when negotiating on behalf of others. Journal of Personality and Social Psychology, 98(2), 256-267.

Arthur, M. B., Inkson, K., \& Pringle, J. K. (1999). The new careers: Individual action and economic change. Thousand Oaks, CA: Sage.

Arthur, M. B., \& Rousseau, D. M. (Eds.). (2001). The boundaryless career: A new employment principle for a new organizational era. New York: Oxford University Press.

Ashford, S. J., Rothbard, N. P., Piderit, S. K., \& Dutton, J. E. (1998). Out On a Limb: The Role of Context and Impression Management in Selling Gender-Equity Issues. Administrative Science Quarterly, 43(1), 23-57. 
Bandura, A. (2001). Social cognitive theory: An agentic perspective. Annual Review of Psychology, 52, 1-26.

Barley, S. R. (1986). Technology as an occasion for structuring: Evidence from observations of CT scanners and the social order of radiology departments. Administrative Science Quarterly, 31, 78-108.

Barley, S. R. (1989). Careers, identities and institutions: The legacy of the Chicago School of Sociology. In M. B. Arthur, D. T. Hall \& B. S. Lawrence (Eds.), Handbook of career theory (pp. 44-65). New York: Cambridge University Press.

Barnard, C. I. (1938). The functions of the executive. Cambridge, MA: Harvard University Press. Baron, J. N., Davis-Blake, A., \& Bielby, W. T. (1986). The structure of opportunity: How promotion ladders vary within and among organizations. Administrative Science Quarterly, 31(2), 248-273.

Berger, J., Fisek, M. H., Norman, R. Z., \& Zelditch, M. E. (1977). Status characteristics and social interaction: An expectation-states approach. New York: Elsevier.

Bielby, W. T., \& Baron, J. N. (1984). A woman's place is with other women: Sex segregation within organizations. In B. F. Reskin (Ed.), Sex Segregation in the workplace: Trends, explanations, remedies. Washington, DC: National Academy Press.

Bielby, W. T., \& Baron, J. N. (1986). Men and women at work: Sex segregation and statistical discrimination. American Journal of Sociology, 91(4), 759-799.

Biernat, M., \& Wortman, C. B. (1991). Sharing of home responsibilities between professionally employed women and their husbands. Journal of Personality and Social Psychology, 60(6), 844-860. 
Bird, B., \& Brush, C. G. (2002). A gendered perspective on organizational creation. Entrepreneurship Theory and Practice, 26(3), 41-65.

Blau, P. M., \& Scott, W. R. (1962). Formal organizations: A comparative approach. San Francisco: Chandler.

Bowles, H. R., Babcock, L., \& Lai, L. (2007). Social incentives for gender differences in the propensity to initiate negotiation: Sometimes it does hurt to ask. Organizational Behavior \& Human Decision Processes, 103, 84-103.

Bowles, H. R., Babcock, L., \& McGinn, K. L. (2005). Constraints and Triggers: Situational Mechanics of Gender in Negotiation. Journal of Personality \& Social Psychology, 89(6), 951-965.

Bowles, H. R., \& McGinn, K. L. (2005). Claiming authority: Negotiating challenges for women leaders. In D. M. Messick \& R. M. Kramer (Eds.), The psychology of leadership: New perspectives and research (pp. 191-208). Mahwah, NJ: Erlbaum.

Brass, D. J. (1984). Being in the right place: A structural analysis of individual influence in an organization. Administrative Science Quarterly, 29(4), 518-539.

Brass, D. J. (1985). Men's and women's networks: A study of interaction patterns and influence in an organization. Academy of Management Journal, 28(2), 327-343.

Brescoll, V. L., \& Ulhmann, E. L. (2008). Can angry women get ahead? Status conferral, gender, and expression of emotion in the workplace. Psychological Science, 19(3), 268-275.

Bruni, A., \& Gherardi, S. (2004). Doing gender, doing entrepreneurship: An ethnographic account of intertwined practices. Gender, Work and Organization, 11(4), 406.

Brush, C. G. (1992). Research on women business owners: Past trends, a new perspective and future directions. Entrepreneurship Theory and Practice, 16(4), 5-30. 
Brush, C. G., Carter, N. M., Gatewood, E., Greene, P. G., \& Hart, M. M. (2004). Clearing the hurdles: Women building high-growth businesses. Upper Saddle River, N.J.: Financial Times-Prentice Hall.

Brush, C. G., Carter, N. M., Gatewood, E. J., Greene, P. G., \& Hart, M. M. (Eds.). (2006). Women and entrepreneurship: Contemporary classics. Northampton, MA: Elgar.

Burt, R. S. (1998). The gender of social capital. Rationality and Society, 10(1), 5-46.

Carli, L. L. (1999). Gender, interpersonal power, and social influence. Journal of Social Issues, 55(1), 81-99.

Catalyst. (1992). On the line: Women's career advancement. New York: Catalyst.

Cejka, M. A., \& Eagly, A. H. (1999). Gender-stereotypic images of occupations correspond to the sex segregation of employment. Personality and Social Psychology Bulletin, 25(4), 413-423.

Cliff, J. E. (1998). Does one size fit all? Exploring the relationship between attitudes towards growth, gender and business size. Journal of Business Venturing, 13, 523-542.

Cohen, L. E., Broschak, J. P., \& Haveman, H. A. (1998). And then there were more? The effect of organizational sex composition on the hiring and promotion of managers. American Sociological Review, 63, 711-727.

DeRue, D. S., \& Ashford, S. J. (2010). Who will lead and who will follow? A social process of leadership identity construction in organizations. Academy of Management Review, 35(4), 627-647.

Doeringer, P. B., \& Piore, M. J. (1985). Internal labor markets and manpower analysis. Armonk, NY: M. E. Sharpe. 
Dutton, J. E., \& Ashford, S. J. (1993). Selling issues to top management. Academy of Management Review, 18(3), 397-428.

Eagly, A. H., \& Carli, L. L. (2007). Through the labyrinth. Boston, MA: Harvard Business School Press.

Eagly, A. H., \& Karau, S. J. (2002). Role congruity theory of prejudice toward female leaders. Psychological Review, 109(3), 573-598.

Eagly, A. H., \& Steffen, V. J. (1984). Gender stereotypes stem from the distribution of women and men into social roles. Journal of Personality and Social Psychology, 46(4), 735-754.

Eagly, A. H., \& Steffen, V. J. (2000). Gender stereotypes stem from the distribution of women and men into social roles Stangor, Charles (Ed). (2000). Stereotypes and prejudice: Essential readings. Key readings in social psychology. (pp. 142-160). Philadelphia, PA, US; Philadelphia, PA, US: Psychology Press/Taylor \& Francis; Psychology Press/Taylor \& Francis.

Edmondson, A. C., \& McManus, S. E. (2007). Methodological fit in management field research. Academy of Management Review, 32(4).

Ely, R. J. (1994). The effects of organizational demographics and social identity on relationships among professional women. Administrative Science Quarterly, 39(2), 203-238.

Ely, R. J. (1995). The power of demography: Women's social constructions of gender identity at work. Academy of Management Journal, 38(3), 589-635.

Ely, R. J., Foldy, E. G., \& Scully, M. A. (Eds.). (2003). Reader in gender, work, and organization. Malden, MA: Blackwell. 
Ely, R. J., Ibarra, H., \& Kolb, D. M. (2011). Taking gender into account: Theory and design for women's leadership development programs. Academy of Management Learning \& Education, 10(3), 474-493.

Flynn, F. J., \& Ames, D. R. (2006). What's good for the goose may not be as good for the gander: The benefits of self-monitoring for men and women in task groups and dyadic conflicts. Journal of Applied Psychology, 91(2), 272-281.

Follett, M. P. (1949). Freedom and co-ordination: Lectures in business organization by Mary Parker Follett. London: Management Publications Trust, Ltd.

Follett, M. P. (1995). The basis of authority. In P. Graham (Ed.), Mary Parker Follett--Prophet of management: A celebration of writings from the 1920s. Boston, MA: Harvard Business School Press.

French, J. R. P., \& Raven, B. (1959). The bases of social power. In D. Cartwright (Ed.), Studies in social power. Ann Arbor: Research Center for Group Dynamics, University of Michigan.

Frenkiel, N. (1984, March). The up-and-comers; Bryant takes aim at the settlers-in. Adweek. Special Report; Magazine World.

Giddens, A. (1979). Central problems in social theory: Action, structure, and contradition in social analysis. Berkeley: University of California Press.

Glaser, B. G., \& Strauss, A. L. (1967). The discovery of grounded theory: Strategies for qualitative research. New York: Aldine de Gruyter.

Goffee, R., \& Scase, R. (1983). Business ownership and women's subordination: A preliminary study of female proprietors. Sociological Review, 31, 625-647. 
Goffee, R., \& Scase, R. (1985). Women in charge: The experience of female entrepreneurs. London: Allen and Unwin.

Goldin, C. (1990). Understanding the gender gap: An economic history of American women. New York: Oxford University Press.

Goldin, C., \& Rouse, C. (2000). Orchestrating impartiality: The impact of "blind" auditions on female musicians. American Economic Review, 90(4), 715-741.

Graham, P. (Ed.). (1995). Mary Parker Follett--Prophet of management: A celebration of writings from the 1920s. Boston, MA: Harvard Business School Press.

Greene, P. G., Brush, C. G., Hart, M. M., \& Saparito, P. (2001). Patterns of venture capital funding: Is gender a factor? Venture Capital, 3(1), 63-83.

Greene, P. G., \& Johnson, M. A. (1995). Social learning and middleman minority theory: Explanations for self-employed women. National Journal of Sociology, 9, 59-84.

Greer, M. J., \& Greene, P. G. (2003). Feminist theory and the study of entrepreneurship. In J. E. Butler (Ed.), New perspectives on women entrepreneurs (pp. 1-24). Greenwich, CT: Information Age Publishing.

Gutek, B. A. (2001). Women and paid work. Psychology of Women Quarterly, 25(4), 379-393.

Gutek, B. A., \& Larwood, L. (Eds.). (1987). Women's career development. Newbury Park, CA: Sage.

Hall, D. T. (1976). Careers in organizations: Individual planning and organizational development. Pacific Palisades, CA: Goodyear Publishing.

Hall, D. T. (2002). Careers in and out of organizations. Thousand Oaks, CA: Sage.

Hall, D. T. (Ed.). (1986). Career development in organizations. San Francisco, CA: Jossey-Bass. 
Handy, C. B. (1998). The age of personal sovereignty (chapter 4) The hungry spirit: Beyond capitalism - a quest for purpose in the modern world. New York: Arrow Books.

Heifetz, R. A. (1994). Leadership without easy answers. Cambridge, MA: Belknap Press of Harvard University Press.

Heilman, M. E. (1983). Sex bias in work settings: The lack of fit model. In B. M. Staw \& L. I. Cummings (Eds.), Research in organizational behavior (Vol. 5, pp. 269-298). Greenwich, CT: JAI.

Hewlett, S. A. (2002). Creating a life: Professional women and the quest for children. New York: Talk Miramax Books.

Higgins, M. C., \& Kram, K. E. (2001). Reconceptualizing mentoring at work: A developmental network perspective. Academy of Management Review, 26(2), 264-288.

Hochschild, A. R. (1990). The second shift: Inside the two-job marriage. New York: Morrow/Avon.

Hochschild, A. R. (1997). The time bind: When work becomes home and home becomes work. New York: Metropolitan Books.

Hymowitz, C., \& Schellhardt, T. D. (1986, March 24). The corporate woman (a special report): Cover -- The glass ceiling: Why women can't seem to break the invisible barrier that blocks them from the top jobs. Wall Street Journal.

Ibarra, H. (1992). Homophily and differential returns: Sex differences in network structure and access in an advertising firm. Administrative Science Quarterly, 37(3), 422-447.

Ibarra, H. (2003). Working identity: Unconventional strategies for reinventing your career. Boston, MA: Harvard Business School Press. 
Ibarra, H., \& Barbulescu, R. (2010). Identity as narrative: Prevalence, effectiveness, and consequences of narrative identity work in macro work role transitions. Academy of Management Review, 35(1), 135-154.

Ibarra, H., Carter, N. M., \& Silva, C. (2010). Why men still get more promotions than women. Harvard Business Review, 88(9), 80-126.

Kanter, R. M. (1977). Men and women of the corporation. New York: Basic Books.

Katz, D., \& Kahn, R. L. (1966). The social psychology of organizations (2nd ed.). New York: Wiley.

Kelman, H. C., \& Hamilton, V. L. (1989). Crimes of obedience: Toward a social psychology of authority and responsibility. New Haven, CT: Yale University Press.

Livingston, R. W., Rosette, A. S., \& Washington, E. F. (2012). Can an agentic Black woman get ahead? The impact of race and interpersonal dominance on perceptions of female leaders. Psychological Science, 23(4), 354-358.

Loscocco, K. A., Robinson, J., Hall, R. H., \& Allen, J. K. (1991). Gender and small business success: An inquiry into women's relative disadvantage. Social Forces, 70(1), 65-85.

Lounsbury, M., \& Glynn, M. A. (2001). Cultural entrepreneurship: Stories, legitimacy, and the acquisition of resources. Strategic Management Journal, 22(6/7), 545.

Lukes, S. (1974). Power: A radical view. Hampshire: Macmillan.

Lyness, K. S., \& Heilman, M. E. (2006). When fit Is fundamental: Performance evaluations and promotions of upper-level female and male managers. Journal of Applied Psychology, 91(4), 777-785.

Lyness, K. S., \& Thompson, D. E. (1997). Above the glass ceiling? A comparison of matched samples of female and male executives. Journal of Applied Psychology, 82(3), 359-375. 
Lyness, K. S., \& Thompson, D. E. (2000). Climbing the corporate ladder: Do female and male executives follow the same route? Journal of Applied Psychology, 85(1), 56-101.

Mainiero, L. A., \& Sullivan, S. E. (2005). Kaleidoscope careers: An alternate explanation for the "opt-out" revolution. Academy of Management Executive, 19(1), 106-123.

Martens, M. L., Jennings, J. E., \& Jennings, P. D. (2007). Do the stories they tell get them the money they need? The role of entrepreneurial narratives in resource acquisition. Academy of Management Journal, 50(5), 1107-1132.

Martin, N. H., \& Strauss, A. L. (1956). Patterns of mobility within industrial organizations. The Journal of Business, 29(2), 101-110.

Meyerson, D. E. (2001). Tempered radicals: How people use difference to inspire change at work. Boston, MA: Harvard Business School Press.

Miles, M. B., \& Huberman, A. M. (1994). Qualitative data analysis: An expanded sourcebook (2nd ed.). Thousand Oaks, CA: Sage.

Milgram, S. (1974). Obedience to authority. New York: Harper Perennial.

Mirchandani, K. (1999). Feminist insight on gendered work: New directions in research on women and entrepreneurship. Gender, Work \& Organization, 6(4), 224-235.

Moore, D. P., \& Buttner, E. H. (1997). Women entrepreneurs: Moving beyond the glass ceiling. Thousand Oaks, CA: Sage.

Moss-Racusin, C. A., \& Rudman, L. A. (2010). Disruptions in women’s self-promotion: The backlash avoidance model. Psychology of Women Quarterly, 34, 186-202.

Newman, K. S. (1999). Falling from grace: Downward mobility in the age of affluence (2nd ed.). Berkely: University of California Press. 
O'Neill, O. A., \& O'Reilly, C. A. (2010). Careers as tournaments: The impact of sex and gendered organizational culture preferences on MBAs' income attainment. Journal of Organizational Behavior, 31(6), 856-876.

Padavic, I., \& Reskin, B. (2002). Women and work. Thousand Oaks, CA: Sage.

Pfeffer, J. (1981). Power in organizations. Boston, MA: Pitman.

Ragins, B. R., \& Sundstrom, E. (1989). Gender and power in organizations: A longitudinal perspective. Psychological Bulletin, 105(1), 51-88.

Reskin, B. F., \& Ross, C. E. (1992). Jobs, authority, and earnings among managers. Work and Occupations, 19(4), 342-365.

Ridgeway, C. L. (1982). Status in groups: The importance of motivation. American Sociological Review, 47(1), 76-88.

Ridgeway, C. L. (2001). Gender, status, and leadership. Journal of Social Issues, 57(4), 637-655.

Ridgeway, C. L. (2011). Framed by gender: How gender inequality persists in the modern world. Oxford, UK: Oxford University Press.

Rosenbaum, J. E. (1979). Tournament Mobility: Career Patterns in a Corporation. Administrative Science Quarterly, 24(2), 220-241.

Rudman, L. A. (1998). Self-promotion as a risk factor for women: The costs and benefits of counterstereotypical impression management. Journal of Personality and Social Psychology, 74(3), 629-645.

Rudman, L. A., \& Glick, P. (2001). Prescriptive gender stereotypes and backlash toward agentic women. Journal of Social Issues, 57(4), 743-762.

Rudman, L. A., \& Glick, P. (2008). The social psychology of gender: How power and intimacy shape gender relations. New York: Guilford. 
Rudman, L. A., \& Kilianski, S. E. (2000). Implicit and explicit attitudes toward female authority. Personality and Social Psychology Bulletin, 26(11), 1315-1328.

Rudman, L. A., \& Phelan, J. E. (2008). Backlash effects for disconfirming gender stereotypes in organizations. Research in Organizational Behavior, 28(0), 61-79.

Schein, E. H. (1978). Career dynamics: Matching individual and organizational needs. Reading, MA: Addison-Wesley.

Schein, E. H. (1984). Culture as an environmental context for careers. Journal of Occupational Behavior, 5, 71-81.

Schein, V. E., Mueller, R., Lituchy, T., \& Liu, J. (1996). Think manager-think male: A global phenomenon? Journal of Organizational Behavior, 17(1), 33-41.

Scott, M. B., \& Lyman, S. M. (1968). Accounts. American Sociological Review, 33(1), 46-62.

Selznick, P. (1957). Leadership in administration. Evanston: Row, Peterson.

Sheridan, J. E., Slocum Jr, J. W., Buda, R., \& Thompson, R. C. (1990). Effects of corporate sponsorship and departmental power on career tournaments. Academy of Management Journal, 33(3), 578-602.

Simon, H. (1976). Administrative Behavior (3rd ed.). New York: Free Press.

Sternin, J., Pascale, R., \& Fisher, M. (2009). Power of positive deviance. Harvard Business School Press Books, 1.

Stinchcombe, A. L. (1986). Stratification and organization: Selected Papers. Cambridge, UK: Cambridge University Press.

Stogdill, R. M. (1953). Leadership, membership and organization. In D. Cartwright \& A. Zander (Eds.), Group dynamics: Research and theory. Evanston, IL: Row, Peterson and Company. 
Strauss, A. L. (1959). Mirrors and masks. New York: Free Press.

Strauss, A. L. (1978). Negotiations: Varieties, contexts, processes, and social order. San Francisco: Jossey-Bass.

Strauss, A. L., \& Corbin, J. (Eds.). (1997). Grounded theory in practice. Thousand Oaks: Sage.

Tharenou, P., Latimer, S., \& Conroy, D. (1994). How do you make it to the top? An examination of influences on women's and men's managerial. Academy of Management Journal, 37(4), 899.

Thatcher, M. (1995). The path to power. New York: HarperCollins.

Thomas, D. A., \& Gabarro, J. J. (1999). Breaking through: The making of minority executives in corporate america. Boston, MA: Harvard Business School Press.

Thomas, D. A., \& Kram, K. E. 1988. Promoting career enhancing relationships in organizations: The role of the human resource professional. In M. London \& E. Mone (Eds.), The human resource professional and employee career development (pp. 49-66). New York: Greenwood.

Thurow, L. C. (1975). Generating inequality: Mechanisms of distribution in the U.S. economy. New York: Basic Books.

Valian, V. (1999). Why so slow? The advancement of women. Cambridge, MA: The MIT Press.

Van Maanen, J. (Ed.). (1976). Organizational careers: Some new perspectives. New York: Wiley.

Van Maanen, J., \& Schein, E. H. (1977). Improving the quality of work life: Career development. In J. R. Hackman \& J. L. Suttle (Eds.), Improving life at work. Santa Monica: Goodyear. 
von Hippel, C., Wiryakusuma, C., Bowden, J., \& Shochet, M. (2011). Stereotype threat and female communication styles. Personality and Social Psychology Bulletin, 37(10), 13121324.

Weber, M. (1947). The theory of social and economic organization (A. M. Henderson \& T. Parsons, Trans.). New York: Oxford University Press.

Weick, K. E. (1979). The social psychology of organizing. Reading, MA: Addison-Wesley.

Weick, K. E. (2001). Enactment and the boundaryless career: Organizing as we work. In M. B. Arthur \& D. M. Rousseau (Eds.), The boundaryless career: A new employment principle for a new organizational era (pp. 40-57). New York: Oxford University Press.

Winn, J. (2004). Entrepreneurship: Not an easy path to top management for women. Women in Management Review, 19(3), 143-153.

Wirth, L. (2001). Breaking through the glass ceiling: Women in management. Geneva, Switzerland: International Labour Office.

Wolf, W. C., \& Fligstein, N. D. (1979). Sex and authority in the workplace: The causes of sexual inequality. American Sociological Review, 44(2), 235-252. 


\section{APPENDIX A: Interview Protocol}

1. Briefly describe your [job/current work].

2. Please tell us the story of how you got [this job/your current position(s)].

3. How you have gained the authority to lead? What factors have strengthened the legitimacy of your leadership? What factors have undermined the legitimacy of your leadership?

4. What were your most pivotal work experiences, in terms of enabling you to obtain your current leadership position?

5. How have you managed to gain the resources and opportunities to become a leader in your field? How do you know when to negotiate and what's negotiable? Have there been times when you wanted access to resources or opportunities for leadership but you were unable to get them?

6. What are the greatest barriers you have faced in attempting to achieve leadership positions?

7. What are your responsibilities outside work? Do you have children? How many? What ages? Do you have a partner with a career?

8. What do you believe distinguishes you from others who have tried, but have ultimately been unable, to achieve similar positions of leadership?

9. What advice would you give to people who aspire to leadership positions?

10. Do you think there is a different set of skills, abilities, or traits for getting into top leadership positions in your field, than for being effective as a leader once you get there? If so, what are the differences?

11. Have you been able to shape people's conception of what the key attributes of leadership should be in your organization? 


\section{APPENDIX B: Supplemental Examples of Navigating and Pioneering Accounts}

Navigating Account
Pioneering Account
Corp: "I had a mental map of what experiences I wanted to allow me ... to be... a top exec. ... [Example:] When I first heard [the CEO] talk about... this [strategic] concept... I went and I found the leader who was going to go solve that problem... I read a bunch of books and I came up with a straw man plan to illustrate my knowledge of what I already knew and my capacity...to learn and contribute. And so that went over great...because there was no expert in our company at the time. So part of being successful here is being able to show influence and drive and have really good strategic thinking... So I got that job and then through that I did all kinds of really neat things.”

Corp: "I've always asked for the position I wanted and I've always gotten it... I guess it is because... I've always been really focused on getting what I want. ... I was working for the existing CFO, but I really wanted to be the CFO. I made my career aspiration known.”

Entre: “[Starting a new business,] I went to talk to [my old customers] ... The fact that I had done a good job for them in the past gave them confidence to say..., 'I'm going to give her a chance. She did good work.' So [my resources were] my... education and my experience, and then... happy customers.”

Entre: "I was the CFO that took the company public... I had a long tenure... and a lot of varied experiences... The career opportunity for me...to stay... was there... I just wasn't interested. I like an entrepreneurial company... I pulled together my resume... and started my list of contacts... That's how you do it. You go to lunch and breakfast... and remind them that you are now looking for a new opportunity."
Corp: "I was... [in marketing], where I had an element of pricing [but] it was really only the license. When [senior executive] came into the organization, I talked to her about what I felt the strategic importance of pricing and licensing was across the organization... So she got it... And we both talked to [the CEO] and said how strategic this was... He got it, too. So we then had this [global] initiative ..., and then that's when I got everything... Anything [in category], I'm responsible for it. And that's pretty much how it happened.... So I wasn't really trying to transform my job per se. I did want to be in charge of it, meaning that I felt, at that point, no one knew it better than me what the issues were. So it wasn't like I was trying to create... a different position for myself. But I was clearly saying this needs to be more of a strategic endeavor, and it really needs to be at the corporate level..."

Entre. “I [am] CEO, basically, because I'm the visionary [based on raising child with a medical condition]. ... On the big vision I was very clear, but the details, I just didn't know... Along the way I learned... So I started developing this wealth of knowledge and understanding, and then the vision kept expanding, and what was possible in terms of innovation. ... So I learned the frustration that caregivers experience. I learned the frustration of clients. Because I've been in their homes, and saw the issues they have... Along the way I gained experience from being in it, and that gave me power. ... I'm the corporate storyteller... That attracts visibility to the company... I was going to open a [new business]... I saw the need, and I was able to address the need... My vision....and my struggle had been going on in their mind... They said, 'Oh, we can help you do it.’” 


\section{Appendix C: Supplemental Examples of Narrative Identity Work Revising Career Stories}

Entre: "I... became unhappy with my job... I could have told my boss, 'Hey,... give me another job,' and he would have done that. But I really saw that as a sign... They weren't managers because they were good managers. They were... managers because they'd been there long enough to become one... I think [that was] the pivotal point in my career ... that... made me say 'this is it. I'm going to do my own thing.' ... I went to talk to [my customers] and I said 'I'm starting my own company and here are some of the things that I can do for you'... My goal [was] to build a company, of course to enhance my life, and then also to enhance the lives of the people that work here at my company.”

Corp: "I went through a really personal struggle... We had jerked our kids around quite a bit... Part of me really just wanted to stop. But I wasn't ready... I went through a debate about whether I should pursue consulting. Should I try to do something else? ... I kept thinking, 'Gosh, I still have this in me. I really want to be a CIO.' I made that decision and started interviewing. I picked [company] and relocated.”

Corp: "I was the CFO at [company]. We grew and went public... I stayed with them [after acquisition, but] I finally got...disgusted and resigned... After talking to about 40 companies, I ended up joining [new company]... The fit...could not have been better... I went [in] feeling confident that my role...would be broad and strategic. ... [CEO] saw that I was a lot broader than just a numbercrunching CFO [and] had the ability to see things strategically.”
Entre: "I was director of marketing [and had strategic idea.] So I put together a business plan for my then bosses... They liked the idea very much... I worked on it for the company ... [Then the division heads] began to get really testy... 'You hired a woman, and she gets her own division? What the hell is going on?' So it was stopped. It was totally separate from whether there was a marketplace for it... That is how I became an entrepreneur. They cancelled it. I was crushed. I said to my husband, 'You won't believe this...' He said, 'Well...' I said, 'Do you think I can do this?'”

Entre: "I had a business fail... I was able to raise two rounds of venture capital... And I was really quite upset about it and I finally called [an investor]..., and I said, 'This is a very tough call for me to make.' And, he said, '...Frankly, I am just waiting for you to come back to me with your next idea.' And that...got me out of my worst piece of that funk, but it still took me about six months to realize that it wasn't me, it was the timing... It was a very important moment.”

Corp: [Immediately after merger] "I did my networking externally, internally..., and every single person I met with said, 'You're dead, you're gone, you'll never survive, they don't care about [your issue.] ... For those [first] months I networked nationally and really was able to slow down and see what is going on. At the end of that I knew that this was so huge and the opportunity was so great that I was recommitted to: 'This is what I really want to do, and I want to do it for a larger company, and it would be great to do this at [newly merged bank].” 
Table 1. Descriptive Statistics on Interviewees at the Time of Interview by Career Context

\begin{tabular}{|c|c|c|c|}
\hline & & \multicolumn{2}{|c|}{ Context of Peak Leadership Position } \\
\hline & & $\begin{array}{c}\text { Corporate } \\
(\mathrm{n}=25)\end{array}$ & $\begin{array}{l}\text { Entrepreneurial } \\
\qquad(\mathrm{n}=25)\end{array}$ \\
\hline Age & $M$ & 49.87 & 49.64 \\
\hline & $S D$ & $(5.80)$ & $(8.71)$ \\
\hline \multirow[t]{2}{*}{ Family Status } & Married $^{*} P$ & .80 & 1.00 \\
\hline & Mother $P$ & .60 & .92 \\
\hline \multirow[t]{3}{*}{ Education } & Bachelor's degree $P$ & 0.96 & .92 \\
\hline & Graduate degree $P$ & 0.76 & .44 \\
\hline & MBA degree $P$ & 0.64 & .32 \\
\hline \multirow[t]{4}{*}{ Location } & Northeast $P$ & .36 & .44 \\
\hline & South $P$ & .20 & .20 \\
\hline & West/Midwest $P$ & .36 & .32 \\
\hline & International $P$ & .08 & .04 \\
\hline \multirow[t]{6}{*}{ Industry } & Consumer Products $P$ & .16 & .04 \\
\hline & Financial Services $P$ & .28 & .20 \\
\hline & Manufacturing $P$ & .12 & .04 \\
\hline & Retail $P$ & .12 & .24 \\
\hline & Technology $P$ & .12 & .28 \\
\hline & Other Services $P$ & .20 & .24 \\
\hline
\end{tabular}

\footnotetext{
${ }^{*}$ Includes women divorced and widowed.
} 
Figure 1. Overview of Data Coding and Analysis

\section{NAVIGATING}

Narrative follows Weberian Logic in which authority claims are based on, "Rationalgrounds - resting on a belief in the 'legality' of patterns of

normative rules and the right of those elevated to a uthority under such rules to issue commands (legal authority)”(Weber, 1947).

\begin{tabular}{|l}
\hline $\begin{array}{l}\text { First-Order Codes } \\
\text { (Examples) }\end{array}$ \\
\hline $\begin{array}{l}\text { - Statements about desired positions } \\
\text { (e.g., CEO, CFO, COO) }\end{array}$ \\
\hline $\begin{array}{l}\text { • Statements about desired job } \\
\text { attributes (e.g., "run a business," "run } \\
\text { my own business," "line } \\
\text { responsibility," "my own work } \\
\text { schedule" for work-family balance) }\end{array}$ \\
\hline
\end{tabular}

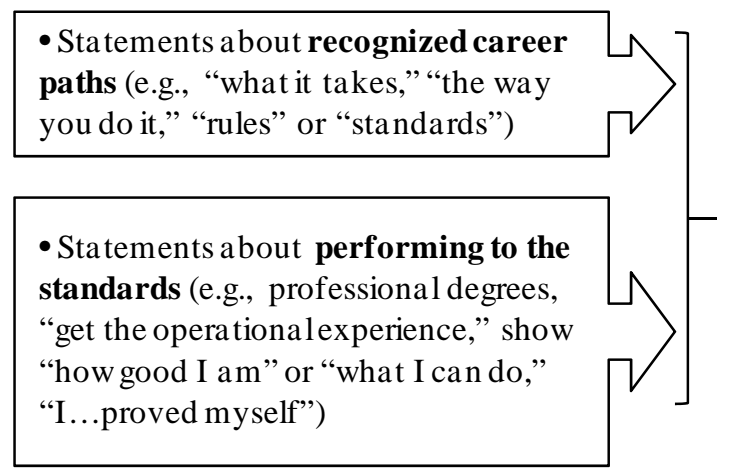

Attain

Leadership

Position

Second-Order

Concepts

Follow the

Rules of

Advancement

within the

Institutionalized

Social Structure

\section{- Statements a bout asking for desired positions or opportunities or otherwise making aspirations known.}

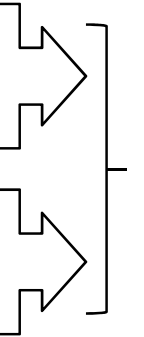

Self-

Advocate

with

- Statements about refusing
undesirable positions (e.g., staff vs.

Gatekeepers

\section{Theoretical Sub-Categories} Authority

line, "I don't like decoration jobs")

\section{PIONEERING}

Narrative follows Follettian Logic in which authority claims are derived from, "our common life. [Authority] does not come from separating people, from dividing them into two classes... It comes from... my work fitting into yours and yours into mine, and from that intermingling of forces a power...[to] control those forces" (Follett, 1949).

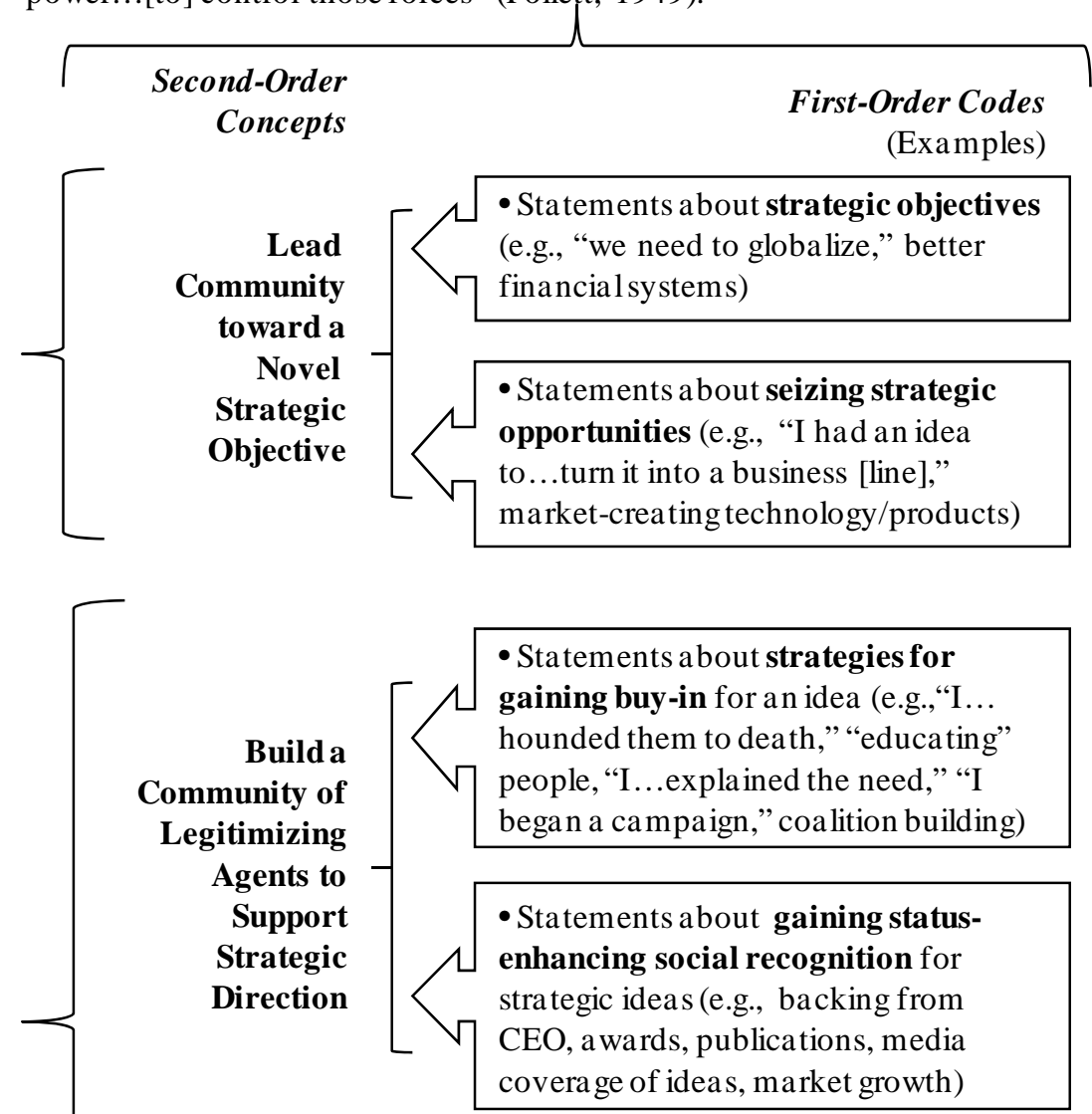

\section{Authority \\ Claims}

1. Aspired Claims

2. Strategies for

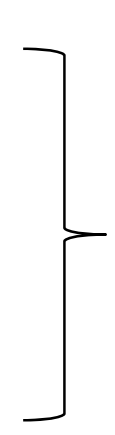

\begin{tabular}{c|l|}
$\begin{array}{c}\text { Identify } \\
\text { Self as }\end{array}$ & $\begin{array}{l}\text { - Statements about identifying herself } \\
\text { as the leader to achieve strategic } \\
\text { Natural } \\
\text { Leader (e.g., attra cting media attention, } \\
\text { "I wanted everybody to know who I } \\
\text { was [and] what I was doing...," writing } \\
\text { book to establish thought leadership) }\end{array}$ \\
\hline
\end{tabular}




\section{- Attainment of desired position or job characteristics and validating ca reer a chievements (e.g., "biggest deal of my career") \\ Authority \\ Claim \\ Validated}

\section{- Statements a bout lack of support}

\section{from gatekeepers of career}

advancement (e.g., "not part of the old

boy network," "lack of sponsorship,"

"more highly valued by my clients than

Authority

Claim

the people I worked with,” fired)

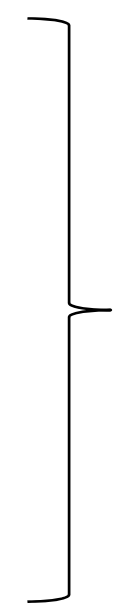

- Statements about disappointment or dissatisfaction with current situation (e.g., "I wasn't happy...I started thinking about what...I want to do")

- Statements about self-insight (e.g., "I learned so much about myself," "I

realized...something...important to me," "that was...turning point for me")
Struggle with Disappointment Leads to New Insights about Job Preferences Authority Claims

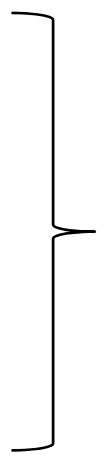

4. Narrative Identity Work

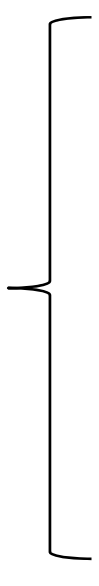

\begin{tabular}{ll|} 
Authority & $\begin{array}{l}\text { • New expanded or elevated role to } \\
\text { lead strategic initiative (e.g., new } \\
\text { balidated } \\
\text { business venture, new/reorganized } \\
\text { business function) }\end{array}$ \\
\hline
\end{tabular}

Authority

Claim

No Validated

- Statements about lack of critical - Statements about lack of critical direction(e.g., ideas ignored or rejected by corpora te lea dership; business failure; fired)

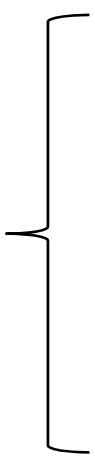

\section{(2) \\ Efforts to Retain Faith Lead to Insights into Self-Potential to Pursue Strategic Ideas

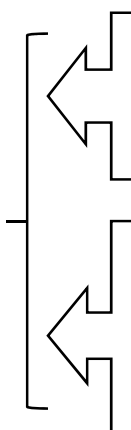

- Statements a bout retaining faith in ideas based on remaining social support (e.g., from followers, funders)

- Statements about insight into selfpotential to pursue ideas (e.g., "an epiphany for me," "I....realize[d] it wasn't me, it was the timing," "that is how I became an entrepreneur") 
Figure 2. Process Model of How Women Legitimize their Claims to Leadership Positions

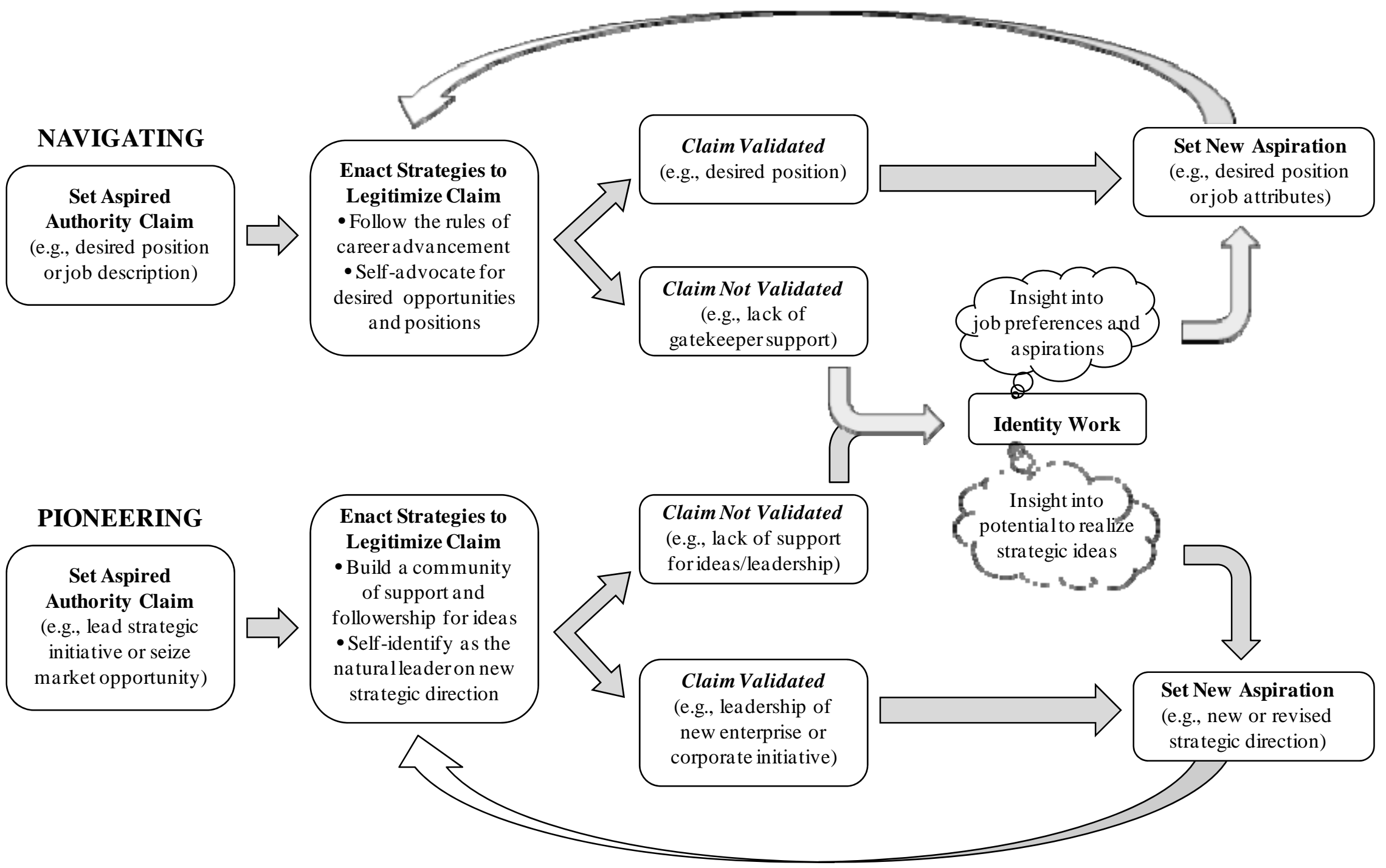

